\title{
The Effect Of Transformational Leadership Style And Work Spirit On Employee Performance At Raffles City Hotel Bengkulu Indonesia
}

\author{
${ }^{1}$ Fachri Arkat \\ ${ }^{2}$ Onsardi \\ ${ }^{12}$ Program Studi Manajemen Universitas Muhammadiyah Bengkulu \\ onsardi@umb.ac.id
}

\begin{abstract}
This research is based on the importance of transformational leadership styles and work morale on employee performance. The formulation of the problem in this study is whether transformational leadership style (X1) and morale (X2) have a significant and partially significant effect on employee performance (Y), the research objective is to determine the effect of transformational leadership style (X1) and morale (X2) on employee performance (Y) raffles city hotel Bengkulu. The object of this study is Bengkulu City Hotel Raffles employees with a total sampling method, which is explained by respondents in this study were 31 employees. Methods of data collection using observation and questionnaires, data analysis techniques using the classic assumption test, descriptive analysis, multiple linear regression analysis and hypothesis testing. The results of this study can be seen from the multiple linear regression test using SPSS namely $\mathrm{Y}=7.175+0.396 \mathrm{X} 1+0.512 \mathrm{X} 2$. The analysis found that transformational leadership style (X1) had a positive effect on employee performance and morale (X2) also had a positive effect on employee performance (Y). Testing the hypothesis of the $t$ test and $F$ test shows that both variables significantly influence employee performance $(\mathrm{Y})$ with a significance level $<0.05$. This means that Ho was refused Ha was accepted.
\end{abstract}

Keywords: Transformational Leadership, Work Spirit, Employee Performance. 


\section{BAB I \\ PENDAHULUAN}

\subsection{Latar Belakang}

Globalisasi dewasa ini, berpengaruh terhadap semua kegiatan manusia baik di negara sendiri maupun ke negara lain. Globalisasi ini mempermudah akses untuk berkunjung ke negara lain dengan syarat tertentu, para pengunjung dari negara lain membutuhkan penginapan ataupun tempat beristirahat, makan solusinya hotel. Dengan kondisi persingan yang semakin tinggi antar perusahaan, setiap perusahaan saling berpacu untiuk memperluas pasar. Harapan dari adanya perluasan pasar secara langsung adalah meningkatnya penjualan, sehingga perusahaan akan memiliki lebih banyak konsumen. Namun ada beberapa hal yang harus dipahami oleh perusahaan selaku produsen, bahwa semakin banyak konsumen maka perusahaan akan semakin sulit mengenali konsumennya secara teliti. Terutama tentang suka atau tidaknya konsumen terhadap barang atau jasa yang di tawarkan dan alasan yang mendasarinya. Perusahaan yang mempu bersaing dengan pasar adalah perusahaan yang dapat menyediakan produk atau jasa berkualitas. Sehingga perusahaan di tuntut untuk terus melakukan perbaikan terutama kualitas pelayanannya.

Perkembangan perekonomian khususnya sektor jasa di Indonesia juga berlangsung pesat. Salah satu sektor jasa yang menjadi andalan Indonesia adalah industri pariwisata yang merupakan salah satu industri yang mampu menjanjikan 
pertumbuhan ekonomi yang cepat. Hotel adalah suatu bentuk bangunan, lambang, perusahaan atau badan usaha akomodasi yang menyediakan pelayanan jasapenginapan, penyedia makanan dan minuman serta fasilitas jasa lainnya dimana semua pelayanan itu diperuntukkan bagi masyarakat umum, baik mereka yang bermalam di hotel tersebut ataupun mereka yang hanya menggunakan fasilitas tertentu yang dimiliki hotel itu. Hotel merupakan sebuah bangunan yang dikelola secara komersial dengan memberikan fasilitas penginapan untuk umum dengan fasilitas pelayanan. Hotel adalah bangunan berkamar banyak yang disewakan sebagai tempat untuk menginap dan tempat makan orang yang sedang dalam perjalanan, atau bentuk akomodasi yang dikelola secara komersial, disediakan bagi setiap orang untuk memperoleh pelayanan, penginapan, makan, dan minum.

Robbins and Judge (2015) gaya kepemimpinan transformasional adalah pemimpin yang menginspirasi para pengikutnya untuk mengesampingkan kepentingan pribadi mereka demi kebaikan organisasi dan mereka mampu memiliki pengaruh yang luar biasa pada diri para pengikutnya. Burns dalam Nurthouse (2013:176) menyatakan kepemimpinan transformasional merupakan proses dimana orang terlibat dengan orang lain, dan menciptakan hubungan yang meningkatkan motivasi dan moralitas dalam diri pemimpin dan pengikut.

Menurut Murdani (2012) semangat kerja adalah kemampuan atau kemauan setiap individu atau sekelompok orang untuk saling bekerja sama dengan giat, tekun dan disiplin serta penuh rasa tanggung jawab disertai kesukarelaan dan kesediaannya 
untuk mencapai sebuah tujuan organisasi. Sedangkan Hendri (2010) mengungkapkan bahwa semangat kerja karyawan adalah sikap mental dari individu maupun kelompok yang menunjukkan kesungguhannya di dalam melaksanakan pekerjaan sehingga mendorong untuk bekerja lebih baik.

Arif Yusuf Hamali (2016) Kinerja merupakan hasil pekerjaan yang mempunyai hubungan yang kuat dengan tujuan strategis organisasi, kepuasan konsumen, dan memberikan kontribusi pada ekonomi. Zainal Arifin (2014) Kinerja merupakan perilaku nyata yang ditampilkan setiap orang sebagai prestasi kerja yang dihasilkan oleh karyawan sesuai dengan perannya dalam perusahaan. Kinerja karyawan merupakan suatu hal yang sangat penting dalam upaya perusahaan untuk mencapai tujuannya.

Raffles City Hotel Bengkulu adalah salah satu penginapan yang ada dan berkembang di JL.Pariwisata No.1, Pantai Panjang kota Bengkulu dengan jumlah karyawan 31 orang,

Untuk meningkatkan kinerja karyawan pihak perusahaan sangat memerlukan gaya kepemimpinan transformasional dan semangat kerja untuk karyawan. Jika gaya kepemimpinan transformasional dapat berjalan dengan lancar tentunya dapat meningkatkan kinerja karyawan sehingga dapat memberikan keuntungan bagi pihak perusahaan. Semangat kerja merupakan suatu kemauan karyawan untuk melakukan pekerjaan sesuai dengan kapasitas masing-masing karyawan yang telah di tetapkan 
oleh perusahaan. Kinerja karyawan merupakan suatu perilaku yang di lakukan oleh karyawan untuk mencapai tujuan perusahaan.

Berdasarkan pengamatan peneliti bahwa di Raffles City Hotel Bengkulu terdapat beberapa karyawan yang sering terlambatan masuk atau bahkan tidak masuk pada saat kerja dan pelayanannya juga terbilang agak lambat. Berdasarkan dari latar belakang penulis tertarik mengambil judul penlitian "pengaruh gaya kepemimpinan transformasional dan semangat kerja terhadap kinerja karyawan Raffles City Hotel Bengkulu".

\subsection{Rumusan Masalah}

Berdasarkan latar belakang di atas maka perumusan masalah dalam penelitian ini adalah :

1. Apakah Gaya Kepemimpinan Transformasional berpengaruh terhadap kinerja karyawan Raffles City Hotel Bengkulu?

2. Apakah Semangat Kerja berpengaruh terhadap kinerja karyawan Raffles City Hotel Bengkulu?

3. Apakah Gaya Kepemimpinan Transformasional dan Semangat Kerja berpengaruh simultan terhadap kinerja karyawan Raffles City Hotel Bengkulu? 


\subsection{Batasan Masalah}

Adapun batasan masalah yang ditentukan penulis maka penulis hanya ingin melakukan penelitian :

1. Peneliti dilakukan pada karyawan Raffles City Hotel Bengkulu.

2. Penelitian hanya di lakukan pada pengaruh gaya kepemimpinan transformasional dan semangat kerja terhadap kinerja karyawan Raffles City Hotel Bengkulu.

\subsection{Tujuan Penelitian}

Berdasarkan latar belakang dan rumusan masalah maka tujuan penelitian ini adalah:

1. Untuk mengetahui pengaruh Gaya Kepemimpinan Transformasional berpengaruh terhadap kinerja karyawan Raffles City Hotel Bengkulu.

2. Untuk mengetahui pengaruh Semangat Kerja berpengaruh terhadap kinerja karyawan Raffles City Hotel Bengkulu.

3. Untuk mengetahui Gaya Kepemimpinan Transformasional dan Semangat Kerja berpengaruh simultan terhadap kinerja karyawan Raffles City Hotel Bengkulu.

\subsection{Manfaat Penelitian}

1. Bagi Peneliti 
Penelitian ini dapat menambah pengetahuan dan pemahaman mengenai manajemen sumber daya manusia secara rill khususnya yang menyangkut gaya kepemimpinan transformasional, semangat kerja, dan kinerja karyawan.

\section{Bagi Universitas}

Dapat memberikan tambahan referensi bagi mahasiswa yang melakukan kajian terhadap ilmu strategi sumber daya manusia.

\section{Bagi Perusahaan}

Hasil penelitian ini diharapkan dapat memberikan bahan pertimbangan berkaitan dengan gaya kepemimpinan transformasional dan semangat kerja untuk meningkatkan kinerja karyawan Raffles City Hotel Bengkulu. 


\section{BAB II}

TINJAUAN PUSTAKA

\subsection{Gaya Kepemimpinan Transformasional}

\subsubsection{Pengartian Gaya Kepemimpinan Transformasional}

Robbins and Judge (2015) gaya kepemimpinan transformasional adalah pemimpin yang menginspirasi para pengikutnya untuk mengesampingkan kepentingan pribadi mereka demi kebaikan organisasi dan mereka mampu memiliki pengaruh yang luar biasa pada diri para pengikutnya. Menurut Yukl (2009:290) kepemimpinan transformasional menyerukan nilai-nilai moral dari pengikut dalam upayanya untuk meningkatkan kesadaran mereka tentang masalah etis dan untuk memobilisasi energi dan sumber daya mereka untuk mereformasi institusi.

Burns dalam Yukl (2009:290) menyatakan “kepemimpinan transformasional adalah gaya kepemimpinan yang menyerukan nilai-nilai moral dari para pengikut dalam upayanya untuk meningkatkan kesadaran mereka tentang masalah etis dan untuk memobilisasi energi dan sumber daya mereka untuk mereformasi institusi. Burns dalam Northouse (2013:17) menyatakan kepemimpinan transformasional adalah merupakan proses dimana orang terlibat dengan orang lain, dan menciptakan hubungan yang menciptakan motivasi dan moralitas dalam diri pemimpin dan 
pengikut. Untuk memilah kompleksitas yang terkait dengan komponen "peningkatan moral" dari kepemimpinan transformasional murni.

\subsubsection{Ciri-ciri Gaya Kepemimpinan Transformasional}

Menurut Burn (dalam Farantia Dindy Devintasari. 2016:24) kepemimpinan transformasional mempunyai ciri-ciri sebagai berikut:

1) Antara pemimpin dan pengikut mempunyai tujuan bersama yang melukiskan nilai-nilai, motivasi, keinginan, kebutuhan, aspirasi, dan harapan mereka. Pemimpin melihat tujuan itu dan bertindak atas namanya sendiri dan atas nama para pengikutnya.

2) Walaupun pemimpin dan pengikut mempunyai tujuan bersama akan tetapi level memotivasi dan potensi mereka untuk mencapai tujuan tersebut berbeda.

3) Kepemimpinan Transformasional berusaha mengembangkan sistem yang sedang berlangsung dengan mengemukakan visi yang mendorong berkembangnya masyarakat baru. Visi ini menghubungkan pemimpin dan pengikutnya kemudian menyatukannya. Keduanya saling mengangkat ke level yang lebih tinggi menciptakan moral yang makin lama makin meninggi. Kepemimpinan Transformasional merupakan kepemimpinan moral yang meningkatkan perilaku manusia. 
4) Kepemimpinan Transformasional akhirnya mengajarkan kepada para pengikut bagaimana menjadi pemimpin dengan melaksanakan peran aktif dalam perusahaan. Keikutsertaan ini membuat pengikut menjadi pemimpin, terlaksananya nilai-nilai akhir yang meliputi kebebasan, kemerdekaan, persamaan dalam masyarakat.

\subsubsection{Dimensi GayaKepemimpinan Transformasional}

Bass dan Avolio (2003) mengemukakan bahwa untuk menghasilkan produktivitas, dimensi/elemen tipe/gaya kepemimpinan transformasional yang mempengaruhi suatu organisasiagar terciptanya tujuan meliputi dimensi/perilaku atau lebih dikenaldengan 4 I sebagai berikut :

1. Idealized influence (pengaruh ideal)

Perilaku pemimpin yang membuatnya dikagumi sehingga pegawaisangat memuji, mengagungkan, mengikuti ddan mencontoh.Pemimpin menunjukkan keyakinan dan daya tarik kepadapengikutnya sehingga terjadi ikatan emosional pada tingkatantertentu.Pengaruh ideal :

1) Menunjukkan keyakinan diri yang kuat.

2) Menghadirkan diri dalam saat sulit.

3) Menunjukkan nilai penting.

4) Menumbuhkan kebanggaan. 
5) Meyakini visi, membanggakan keutamaan visi dan secara pribadi bertanggung jawab kepadatindakan.

6) Menunjukkan kepatuhan pada tujuan.

7) Meneladaniketekunan alam semesta.

2. Inspirational motivation (motivasi inspirasi)

Perilaku pemimpin mengartikulasikan visi yang mendorong dan memberi inspirasi pengikutnya. Pemimpin memberi tantangan kepada pengikut untuk memenuhi standar yang lebih tinggi, mengkomunikasikan optimisme tentang pencapaian tujuan masa depan dan memberi tugas yang berarti. Motivasi inspirasi adalah:

1) Menginspirasi pegawai mencapai kemungkinan yang tidak terbayangkan;

2) Menyelaraskan tujuan individu dan organisasi.

3) Memandang ancaman dan persoalan sebagai kesempatan belajar dan prestasi.

4) Menggunakan kata membangkitkan semangat.

5) Menggunakan symbol.

6) Menampilkan visi yang menggairahkan.

7) Member makna pada apa yang dilakukan.

8) Menciptakan budaya dimana kesalahan yang terjadi dipandang sebagai pengalaman belajar. 
3. Intellectual stimulation (stimulasi intelektual)

Pemimpin mau ambil resiko danmeminta ide pengikutnya membangkitkan semangat dan mendorong kreativitas pengikutnya.Visi pemimpin menjadi kerangka pikir pengikut untuk menghubungkannya dengan pimpinan, organisasi dan sesame mereka serta tujuan organisasi. Stimulasi intelektual adalah:

1) Mempertanyakan status quo.

2) Mendorong pemanfaatan imajinasi.

3) Mendorong penggunaan intuisi yang dipadu dengan logika.

4) Mengajak melihat perspektif baru.

5) Memakai symbol pendukung inovasi.

6) Mempertanyakan asumsi lama.

4. Individualized concideration (pertimbangan individu).

Pemimpin hadir ketika pengikut membutuhkan, pimpinan ini bertindak sebagai mentor, mendengar apa yang menjadi perhatian dan kebutuhan pengikut, termasuk kebutuhan dihormati dan menghargai kontribusi individual terhadap organisasi. Pertimbangan individu sbb:

1) Merenung, memikirkan dan mengidentifikasi kebutuhan individu.

2) Mengidentifikasi kemampuan pegawai.

3) Memberi kesempatan belajar. 
4) Mendelegasikan wewenang.

5) Melatih dan memberi umpan balik pengembangan diri.

6) Mendengar dengan perhatian penuh.

7) Memberdayakan bawahan.

\subsubsection{Indikator Gaya Kepemimpinan Transformasional}

Ada beberapa indikator gaya kepemimpinan transformasional menurut Robbins (2010:263) :

1) Kharisma

Karisma dianggap sebagai kombinasi dari pesona dan daya tarik pribadi yang berkontribusi terhadap kemampuan luar biasa untuk membuat orang lain mendukung visi dan juga mempromosikannya dengan bersemangat. Pemimpin karismatik adalah pemimpin yang mewujudkan atmosfir motivasi atas dasar komitmen dan identitas emosional pada visi, filosofi, dan gaya mereka dalam diri bawahanya

2) Motivasi Inspiratif

Motivasi inspiratif menggambarkan pemimpin bergairah dalam mengkomunikasikan masa depan organisasi yang idealis. Pemimpin menggunakan komunikasi verbal atau penggunaan simbol-simbol yang ditujukan untuk memacu semangat bawahan. Pemimpin memotivasi bawahan akan arti penting visi dan misi 
organisasi sehingga seluruh bawahannya terdorong untuk memiliki visi yang sama. Kesamaan visi ini memacu bawahan untuk bekerja sama mencapai tujuan jangka panjang dengan optimis. Sehingga pemimpin tidak saja membangkitkan semangat individu tapi juga semangat tim.

3) Stimulasi Intelektual

Stimulasi intelektual menggambarkan pemimpin mampu mendorong karyawan untuk memecahkan masalah lama dengan cara yang baru. Pemimpin berupaya mendorong perhatian dan kesadaran bawahan akan permasalahan yang dihadapi. Pemimpinan kemudian berusaha mengembangkan kemampuan bawahan untuk menyelesaikan permasalahan dengan pendekatan-pendekatan atau perspektif baru.

4) Perhatian yang Individual

Perhatian yang individual menggambarkan bahwa pimpinan selalu memperhatikan karyawannya, memperlakukan karyawan

secara individual, melatih dan menasehati. Pemimpin mengajak karyawan untuk jeli melihat kemampuan orang lain. Pemimpin memfokuskan karyawan untuk mengembangkan kelebihan pribadi.

\subsection{Semangat Kerja}

\subsubsection{Pengertian Semangat Kerja}


Menurut Halsey (2003 :305), semangat kerja merupakan sikap kesediaan perasaan yang memungkinkan seseorang bekerja untuk menghasilkan kerja lebih banyak dan lebih baik. Siswanto (2002:282) mendefinisikan semangat kerja sebagai suatu kondisi rohaniah, atau perilaku individu tenaga kerja dan kelompok-kelompok yang menimbulkan kesenangan yang mendalam pada diri tenaga kerja untuk bekerja dengan giat dan konsekuen dalam tujuan yang telahdiitetapkan perilsahaan.

Panggabean (2002:21) yang mengartikan Semangat kerja adalah kondisi dari sebuah kelompok dimana ada tujuan yang jelas, Tujuan yang dimaksudkan disini salah satunya adalah kinerja karyawan yang optimal. Semangat kerja adalah istilahistilah yang menyangkut keperluan diluar pekerjaan seperti pendapatan, rasa aman, kedudukannya lebih tinggi dalam masyarakat. Tohardi (2006:428). Semangat kerja adalah keinginan dan kesungguhan seseorang mengerjakan dengan baik serta berdisiplin untuk mencapai prestasi kerja yang maksimal Hasibuan (dalam Febby Novianti Ginting. 2018:5) Semangat kerja adalah kemampuan sekelompok orangorang untuk bekerja sama dengan giat dan konsekuen dalam mengerjar tujuan bersama. Tohardi (dalam dalam Febby Novianti Ginting. 2018:5).

Menurut Nurmansyah (2011) mengemukakan bahwa semangat kerja adalah melakukan pekerjaan secara lebih semangat sehingga pekerjaan akan dapat diharapkan lebih cepat dan lebih baik. Nitisemito (2010 : 160) semangat kerja adalah “ melakukan pekerjaan secara lebih giat, sehingga dengan demikian pekerjaan akan diharapkan lebih cepat dan lebih baik". Semangat kerja atau moral kerja adalah sikap- 
sikap dari individu-individu maupun kelompok-kelompok terhadap lingkungan kerjanya dan terhadap kesukarelaannya untuk bekerja sama agar dapat mencurahkan kemampuannya secara menyeluruh dengan kebutuhan utama organisasi Westra (dalam Ahmad Yofandi. 2017:1018-1019).

\subsubsection{Cara untuk Meningkatkan Semangat Kerja Karyawan}

Menurut Nitisemito (dalam Aprina Wardani. 2017:39) ada beberapa cara untuk meningkatkan semangat kerja karyawan, caranya dapat bersifat materi maupun non materi, yaitu:

1) Gaji yang sesuai dengan pekerjaan

Salah satu yang terpenting di dalam pekerjaan adalah gaji, jika gaji dalam pekerjaan tersebut sesuai bahkan diberi lebih dengan pekerjaan yang di embaninya maka karyawan tersebut akan bersemangat dalam kerjanya.

2) Memperhatikan kebutuhan rohani

Kebutuhan manusia yang berkaitan dengan psikologis dirinya yang merasakan atau membutuhkan kebutuhan rohani itu bukanlah fisik manusia sendiri, melainkan jwa manusia yang paling dalam. Kebutuhan rohani berkaitan dengan tuntutan perasaan, etika, dan keyakinan manusia demi terpenuhinya kepuasan batin.

3) Sekali-kali perlu menciptakan suasana kerja yang santai yang dapat mengurangi beban kerja 
Karyawan yang merasa bahagia dalam bekerja akan cenderung lebih produktif, kreatif, loyal dan kecil kemungkinannya untuk meningglkan perusahaan. Maka dari itu sangat penting bagi pemimpin untuk menciptakan suasana kerja atau budaya perusahaan yang dapat membuat nyaman atau menyenangkan untuk para karyawannya dengan salah satu cara yaitu menciptakan suasana kerja yang santai dan dapat mengurangi beban kerja tersebut.

4) Harga diri karyawan perlu mendapatkan perhatian

Bila perusahaan ingin mendapatkan kontribusi maksmal dari para karyawan, maka para pemimpin di perusahaan harus memiliki kemampuan untuk mengelola dan meningkatkan harga diri, dan rasa percaya diri dari karyawan untuk menghasilkan hasil yang maksimal.

5) Tempatkan para karyawan pada posisi yang tepat

Tujuan penempatan pegawai ini adalah untuk menempatkan orang yang tepat dan jabatan yang sesuai dengan minat dan kemampuannya, sehingga sumber daya manusia yang ada menjadi produktif.

6) Berikan kesempatan pada mereka yang berprestasi

Cara untuk mempertahankan karyawan agar mau tetap bekerja di perusahaan yang di pimpin beragam, salah satunya adalah dengan memberikan apresiasi kepada karyawan. Apresiasi itu selain gaji, bisa dalam bentuk bonus yang memang 
sesuai dengan kinerja yang dilkukannya yang akan berdampak dan berkesan bahwa perusahaan sangat mengapresiasi dan menghargai karyawan tersebut.

7) Perasaan aman menghadapi masa depan perlu diperhatikan

Wajar saat kita takut pada hal yang sulit di prediksi contohnya adalah ketakutan terhadap masa depan yang memang belum terjadi, kita harus memiliki perasaan takut, takut justru membuat manusia lebih produktif sehingga tetap diperlukan namun takut menjadi tidak baik jika berlebihan malah melumpuhkan aktivitas atau menjadi tidak produktif.

8) Usahakan para karyawan memiliki loyalitas dan keperdulian terhadap organisasi

Ketika sekumpulan orang berada dalam satu wadah yang sama-sama berusaha untuk mencapai tujuan yang sama dengan secara efektif dan efisien bisa diartikan bahwa ini adalah bentuk organisasi, dalam mencapai tujuan organisasi tentunya membutuhkan kerjasama dari setiap personel dan kinerja yang baik dan pentingnya memiliki loyalitas dalam bekerja agar tercapainya kesetiaan karyawan terhadap organisasi.

9) Sekali-kali para karyawan perlu diajak berunding untuk membahas kepentingan bersama

Dengan cara berdiskusi mengajak para karyawan berunding untuk membahas kepentingan bersama tentunya akan berdampak baik terhadap perusahaan, dengan 
saling mengajukan pendapat dan membuat perbandingan pendapat mana yang terbaik yang akan di ambil dan di jalankan demi kemajuan organisasi tersebut.

10) Pemberian insentif yang terarah dalam aturan yang jelas

Dorongan pada seseorang agar mau bekerja dengan baik dan agar lebih dapat mencapai tingkat kinerja yang lebih tinggi sehingga dapat membangkitkan gairah kerja dan motivasi seorang karyawan dalam aturan yang jelas yang telah ditetapkan, jadi seorang akan bekerja dengan baik apabila dirinya terdapat motivasi.

\subsubsection{Indikator Semangat Kerja}

Menurut Maier (dalam Aprina Wardani. 2017:40) seseorang yang memiliki semangat kerja yang tinggi mempunyai alasan tersendiri untuk bekerja yaitu benarbenar menginginkannya. Ada empat indikator yang menunjukkan seseorang mempunyai semangat kerja yang tinggi, yaitu:

1) Kegairahan atau antusiasme (zeast, antuciasm)

Seseorang yang memiliki kegairahan dalam bekerja mengindikasikan bahwa karyawan memiliki motivasi dan dorongan bekerja. Motivasi tersebut akan terbentuk bila seseorang memiliki keinginan atau minat dalam mengerjakan pekerjaannya dengan baik dan yang lebih di pentingkan lagi oleh paea karyawan adalah seharusnya bekerja untuk organisasi bukan lebih mementingkan pada apa yang mereka dapat. 
2) Kekuatan untuk melawan frustasi (resistance of frustration)

Seseorang yang mempunyai semangat kerja yang tinggi tidak memiliki sikap yang pesimistis apabila menemui kesulitan dalam pekerjaannya. Aspek ini menunjukkan adanya kekuatan seseorang untuk selalu konstruktif walaupun sedang mengalami kegagalan yang ditemuinya dalam bekerja. Seseorang yang mempunyai semangat kerja yang tinggi tentunya tidak akan memiliki sifat pesimis apabila menemui kesulitan dalam pekerjaannya.

3) Kualitas untuk bertahan (staying quality)

Aspek ini tidak langsung menyatakan seseorang yang memiliki semangat kerja yang tinggi maka tidak mudah putus asa dalam menghadapi kesukarankesukaran di dalam pekerjaannya, ini berarti bahwa terdapat ketekunan dan keyakinan penuh dalam dirinya. Keyakinan ini menunjukkan bahwa seseorang yang mempunyai energi dan kepercayaan untuk memandang masa yang akan datang dengan baik akan meningkatkan kualitas untuk bertahan. Hal ini yang meningkatkan kualitas untuk bertahan, ketekunan mencerminkan seseorang memiliki kesungguhan dalam bekerjanya, sehingga tidak menganggap bahwa bekerja bukan hanya menghsilkan waktu saja, melainkan sesuatu yang penting.

4) Semangat berkelompok (team spirit) 
Semangat berkelompok menggambarkan hubungan antar karyawan. Dengan adanya semangat kerja, maka para karyawan memiliki sikap kesediaan untuk bekerja sama dengan orang lain agar dapat mencapai tujuan bersama. Lingkungan kerja yang baik, menciptakan suasana kerja yang baik pula, kebersamaan diantara karyawan dengan membagi pekerjaan secara adil mampu meningkatkan semangat kerja bagi karyawan itu sendiri. Jadi semangat kerja disini adanya kesediaan untuk bekerja sama dan tolong menolong dengan orang lain agar dapat mencapai tujuan bersama.

\subsection{Kinerja Karyawan}

\subsubsection{Pengertian Kinerja Karyawan}

Mangkunegara (2006) dan (Onsardi, 2019).kinerja adalah hasil kerja secara kualitas dan kuantitas yang dicapai oleh seorang pegawai dalam melaksanakan tugas yang diberikan kepadanya dan didefinisikan kinerja sebagai hasil kerja yang dapat

dicapai seseorang atau sekelompok orang dalam suatu organisasi dalam rangka mencapai tujuan organisasi dalam periode waktu tertentu, penampilan cara-cara untuk menghasilkan sesuatu hasil yang diperoleh dengan aktivitas yang dicapai dengan suatu unjuk kerja.Umam (2010) dan Anjani, R. (2019) kinerja merupakan kualitas dan kuantitas dari suatu hasil kerja(output) individu maupun kelompok dalam suatu aktivitas tertentu yang diakibatkan oleh kemampuan alami atau kemampuan yang diperoleh dari proses belajar serta keinginan untuk berprestasi. Maulizar (2012:60) kinerja karyawan adalah hasil kerja yang dicapai oleh karyawan dalam suatu 
organisasi sesuai dengan wewenang dan tanggung jawab yang diberikan organisasi dalam upaya mencapai visi, misi, dan tujuan organisasi bersangkutan secara legal, tidak melanggar hukum dan sesuai dengan moral maupun etika.

Menurut Amstrong dan Baron (dalam Dikki Murvi. 2015:32) mengatakan "kinerja merupakan sarana untuk mendapatkan hasil lebih baik dari organisasi, tim, dan individu dengan cara memahami dan mengelola kinerja dalam kerangka tujuan dan standar, dan persyaratan atribut yang disepakati. Bastian (dalam Dikki Murvi. 2015:32) menyatakan bahwa "kinerja adalah gambaran mengenai tingkat pencapaian pelaaksanaan suatu kegiatan atau program atau kebijaksanaan dalam mewujudkan sasaran, tujuan, visi dan misi organisasi yang tertuang dalam perumusan skema strategi suatu organisasi. Kinerja adalah tentang melakukan pekerjaan dan hasil yang dicapai dari pekerjaan tersebut Hamali (dalam Aprina Wardani. 2017:52).

\subsubsection{Penilaian Kinerja}

Pada prinsipnya penilaian kinerja adalah merupakan cara pengukuran kontribusi-kontribusi dari individu dalam instansi yang dilakukan terhadap organisasi. Nilai penting dari penilaian kinerja adalah menyangkut penentuan tingkat kontribusi individu atau kinerja yang diekspresikan dalam penyelesaian tugas-tugas yang menjadi tanggung jawabnya. Penilaian kinerja intinya adalah untuk mengetauhi seberapa produktif seorang karyawan dan apakah ia bisa berkinerja sama atau lebih efektif pada masa yang akan datang, sehingga karyawan, organisasi dan masyarakat memperoleh manfaat. Tujuan dan pentingnya penilaian kinerja berdasarkan sebuah 
studi yang dilakukan akhir-akhir ini mengidentifikasikan dua puluh macam tujuan informasi kinerja yang berbeda-beda, yang dikelompokkan dalam 4 kategori yaitu:

1) Evaluasi yang menekankan perbandingan antar orang.

2) Pengembangan yang menekankan perubahan-perubahan dalam diri seseorang dengan berjalannya waktu.

3) Pemeliharan sistem.

4) Dokumentasi keputusan-keputusan sumber daya manusia. Menurut George dan Jones (dalam Yasha Aulia 2016:31-32) bahwa kinerja dapat dinilai dari kuantitas, kuantitas kerja yang dihasilkan dari sumber daya manusia dan level dari pelayanan pelanggan. Kuantitas kerja yang dimaksud adalah jumlah pekerjaan yang terselesaikan, sedangkan kualitas kerja yang dimaksud adalah mutu dari pekerjaan. Robbins (dalam Yasha Aulia 2016:31-32) menyatakan bahwa ada tiga kriteria dalam melakukan penilaian kinerja individu yaitu:

1) Tugas individu.

2) Perilaku individu.

3) Ciri individu.

\subsubsection{Manfaat Penilaian Kinerja}

Menurut Notoatmodjo (2003:94), adalah sebagai berikut: 
1) Peningkatan prestasi kerja dengan adanya penilaian, baik manajer maupun karyawan memperoleh umpan balik, dan mereka dapat memperbaiki pekerjaan mereka.

2) Kesempatan kerja yang adil dengan adanya penilaian kerja yang akurat, akan menjamin setiap karyawan akan memperoleh kesempatan menempati posisi pekerjaan sesuai dengan kemampuannya.

3) Kebutuhan-kebutuhan pelatihan pengembangan Melalui penilaian prestasi kerja, akan dideteksi karyawan-karyawan yang kemampuannya rendah, dan kemudian memungkinkan adanya program pelatihan untuk meningkatkan kemampuan mereka.

4) Penyesuaian kompensasi Penilaian prestasi kerja dapat membantu para manajer untuk mengambil keputusan dalam menentukan perbaikan pemberian kompensasi, gaji, bonus, dan sebagainya.

5) Keputusan-keputusan promosi dan demosi Hasil penilaian prestasi kerja terhadap karyawan dapat digunakan untuk mengambil keputusan untuk mempromosikan karyawan yang berprestasi baik, dan demosi untuk karyawan yang berprestasi jelek.

6) Kesalahan-kesalahan desain pekerjaan Hasil penilaian prestasi kerja dapat digunakan untuk menilai desain kerja, artinya, hasil penilaian prestasi kerja ini dapat membantu mendiagnosis kesalahan-kesalahan desain kerja. 
7) Penyimpangan-penyimpangan proses rekrutmen dan seleksi Penilaian prestasi kerja dapat digunakan untuk menilai proses rekrutmen dan seleksi karyawan yang telah lalu. Prestasi kerja yang sangat rendah bagi karyawan baru adalah mencerminkan adanya penyimpangan-penyimpangan proses rekrutmen dan seleksi.

\subsubsection{Indikator Kinerja Karyawan}

Menurut Setiawan (2014:1477) untuk mengukur kinerja dapat menggunakan indikator-indikator sebagai berikut:

1) Ketepatan penyelesaian tugas

merupakan pengelolaan waktu dalam bekerja dan juga ketepatan karyawan dalam menyelesaikan pekerjaan

2) Kesesuaian jam kerja

kesediaan karyawan dalam mematuhi peraturan perusahaan yang berkaitan dengan ketepatan waktu masuk/pulang kerja dan jumlah kehadiran.

3) Tingkat kehadiran

Jumlah ketidak hadiran karyawan dalam suatu perusahaan selama periode tertentu.

4) Kerjasama antar karyawan 
Kemampuan karyawan untuk bekerja sama dengan orang lain dalam menyelesaikan suatu tugas yang ditentukan sehingga mencapai daya guna dan hasil guna yang sebesar-besarnya.

5) Kepuasan dalam bekerja

Karyawan merasa puas dengan jenis pekerjaan yang menjadi tanggung jawabnya dalam perusahaan.

\subsection{Hubungan Antar Variabel}

Dalam usaha meningkatkan kinerja karyawan peran gaya kepemimpinan transformasional dan semangat kerja sangat di perlukan, dengan di adakannya suatu gaya kepemimpinan transformasional dan semangat kerja sehingga dapat menciptakan kinerja karyawan Raffles City Hotel Bengkulu.

\subsubsection{Hubungan Gaya Kepemimpinan Transformasional Terhadap Kinerja Karyawan}

Gaya Kepemimpinan merupakan suatu cara yang dimiliki oleh seseorang dalam memengaruhi sekelompok orang atau bawahan untuk bekerja sama dan berdaya upaya dengan penuh semangat dan keyakinan untuk mencapai tujuan yang telah ditetapkan. Artinya, gaya kepemimpinan dapat menuntun pegawai untuk bekerja lebih giat, lebih baik, lebih jujur dan bertanggungjawab penuh atas tugas yang 
diembannya sehingga meraih pekerjaan dapat diselesaikan dengan baik. Hubungan pimpinan dan bawahan dapat diukur melalui penilaian pekerja terhadap gaya kepemimpinan para pemimpin dalam mengarahkan dan membina para bawahannya untuk melaksanakan pekerjaan (Hadar, 2003). Dapat dikatakan bahwa mutu kepemimpinan yang terdapat dalam suatu organisasi memainkan peranan yang sangat dominan dalam keberhasilan organisasi tersebut dalam menyelenggarakan berbagai kegiatannya terutama terlihat dalam kinerja para pegawainya (Siagian, 2003).

(Mondiani, 2012), (Paracha et al., 2012) dan (Pradeep and Prabhu, 2011) yang menyatakan bahwa gaya kepemimpinan transformasional berpengaruh positif dan signifikan terhadap kinerja karyawan. Soekarini (dalam Corry Magdalena. 2016) menunjukkan bahwa kepemimpinan transformasional memberikan pengaruh positif dan signifikan terhadap kinerja karyawan. Waridin dan Guritno (dalam Marisatul Kiptiyah. 2015) menunjukkan bahwa perilaku misalnya pola dan gaya kepemimpinan berpengaruh terhadap kinerja pegawai. Hal ini juga didukung penelitian yang dilakukan oleh Modiani (2012) yang menyimpulkan bahwa kepemimpinan transformasional berpengaruh positif terhadap kinerja karyawan.

Dapat di simpulkan bahwa Gaya Kepemimpinan Transformasional merupakan salah satu faktor penting dalam bekerja, dan memiliki pengaruh terhadap kinerja karyawan. 


\subsubsection{Hubungan Semangat Kerja Terhadap Kinerja Karyawan}

Semangat kerja merupakan suatu cara yang harus dimiliki dalam suatu organisasi utuk mencapai tujuan kinerja yang baik. Artinya semangat kerja dapat memperngaruhi kinerja karyawan tersebut, sehingga karyawan tersebut lebih bertanggung jawab atas kerja yang diembannya dan menangani perkerjaan tersebut dengan baik. Dengan adanya semangat kerja tersebut, maka pekerjaan akan menjadi lebih cepat di selesaikan, kerusakan dapat dikurangi, absensi akan dapat diperkecil, kemungkinan perpindahan karyawan dapat diperkecil seminimal mungkin, dan sebagainya. Oleh karena itulah maka sudah selayaknya apabila setiap perusahaan selalu berusaha agar para karyawan mempunyai semangat kerja yang tinggi, dengan semangat kerja yang dimiliki karyawan maka akan dapat meningkatkan kinerja karena mereka yakin atas kemampuan yang mereka miliki untuk menyelesaikan tugas dengan baik.

Harefa (2009) yang menunjukkan bahwa semangat kerja berpengaruh signifikan terhadap kinerja karyawan. Siti Nurhendar (dalam Arini Diana Yasmin. 2014) Menyatakan bahwa dengan semangat kerja yang tinggi maka kinerja karyawan akan meningkat karena para karyawan akan dapat bekerja sama dengan individu lainnya secara maksimal. Richard Y. Sangki dkk (dalam Rikindaka Awaliwinda. 2014) menyatakan bahwa Semangat kerja berpengaruh signifikan terhadap kinerja karyawan. 
Rina Dwi Handayani (dalam Rikindaka Awaliwinda. 2016) bahwasanya semangat kerja memiliki pengaruh yang signifikan terhadap kinerja. Siti Nurhendar (2007) menunjukkan bahwa dari hasil secara umum responden memberikan tanggapan positif terhadap variabel stres kerja dan semangat kerja kaitannya dengan kinerja karyawan.

Dapat di simpulkan bahwa Semangat Kerja merupakan salah satu faktor penting dalam bekerja, dan memiliki pengaruh terhadap kinerja karyawan.

\subsection{Penelitian Terdahulu}

\section{Tabel 2.1}

\begin{tabular}{|c|c|c|c|c|}
\hline No. & Penulis & Judul Penelitian & Metode & Hasil \\
\hline 1 & $\begin{array}{ll}\text { Yuyun } \quad \text { Fitri } \\
\text { Astuti } \\
(2015)\end{array}$ & $\begin{array}{l}\text { Pengaruh Gaya } \\
\text { Kepemimpinan } \\
\text { Transformasional } \\
\text { Dan Kompensasi } \\
\text { Terhadap } \\
\text { Kinerja Karyawan } \\
\text { Pamella } \\
\text { Supermarket } 7\end{array}$ & Kuantitatif & $\begin{array}{l}\text { Hasil penelitian ini } \\
\text { menunjukkan dari } \\
\text { hasil perhitungan } \\
\text { dalam pembahasan } \\
\text { diketahui Gaya } \\
\text { Kepemimpinan } \\
\text { Transformasional } \\
\text { berpengaruh positif } \\
\text { dan signifikan } \\
\text { terhadap kinerja } \\
\text { karyawan Pamella } \\
\text { Supermarket } 7\end{array}$ \\
\hline
\end{tabular}




\begin{tabular}{|c|c|c|c|c|}
\hline 2 & $\begin{array}{l}\text { H.M. Nawawi } \\
\text { D. Sibali } \\
(2012)\end{array}$ & $\begin{array}{l}\text { Pengaruh Gaya } \\
\text { Kepemimpinan } \\
\text { Transformasional } \\
\text { Terhadap } \\
\text { Kinerja Karyawan } \\
\text { Pada Pt Berau Coal } \\
\text { Kabupaten Berau }\end{array}$ & Kuantitatif & $\begin{array}{l}\text { Hasil penelitian ini } \\
\text { menunjukkan hasil } \\
\text { pembahasan } \\
\text { diketahui Gaya } \\
\text { kepemimpinan } \\
\text { transformasional } \\
\text { berpengaruh } \\
\text { signifikan dan positif } \\
\text { terhadap } \\
\text { kinerja karyawan pada } \\
\text { PT BERAU COAL } \\
\text { Kabupaten Berau. }\end{array}$ \\
\hline No. & Penulis & Judul Penelitian & Metode & Hasil \\
\hline 3 & $\begin{array}{l}\text { Ihsan } \\
\text { Nadjamuddin } \\
(2010)\end{array}$ & $\begin{array}{l}\text { Pengaruh Semangat } \\
\text { Kerja Dan } \\
\text { Kecerdasan } \\
\text { Emosional } \\
\text { Terhadap Kinerja } \\
\text { Karyawan } \\
\text { Studi Kausal } \\
\text { Wisma } \\
\text { Bantimurung - } \\
\text { Jakarta }\end{array}$ & Kuantitatif & $\begin{array}{l}\text { Hasil penelitian ini } \\
\text { menunjukkan } \\
\text { Semangat } \\
\text { Kerja } \\
\text { berpengaruh } \\
\text { signifikan terhadap } \\
\text { kinerja karyawan } \\
\text { Kausal Wisma } \\
\text { Bantimurung Jakarta }\end{array}$ \\
\hline 4 & $\begin{array}{l}\text { Ishak Syahropi } \\
\text { (2016) }\end{array}$ & $\begin{array}{l}\text { Pengaruh } \\
\text { Semangat Kerja } \\
\text { Terhadap Kinerja } \\
\text { Karyawan Pt. } \\
\text { Bangkinang Di } \\
\text { Pekanbaru } \\
\text { (Studi Kasus Pada } \\
\text { Karyawan Tetap } \\
\text { Pt. Bangkinang) }\end{array}$ & Kuantitatif & $\begin{array}{l}\text { Pengaruh semangat } \\
\text { kerja memiliki } \\
\text { tanggapan yang baik } \\
\text { dari responden, } \\
\text { dimana } \\
\text { dibuktikan dengan } \\
\text { nilai t hitung } \\
\text { variabel semangat } \\
\text { kerja. Tapi } \\
\text { berpengaruhnya } \\
\text { semangat kerja } \\
\text { berdampak positif dari } \\
\text { kinerja karyawan Pt, } \\
\text { Bangkinang }\end{array}$ \\
\hline
\end{tabular}




\subsection{Kerangka Konseptual}

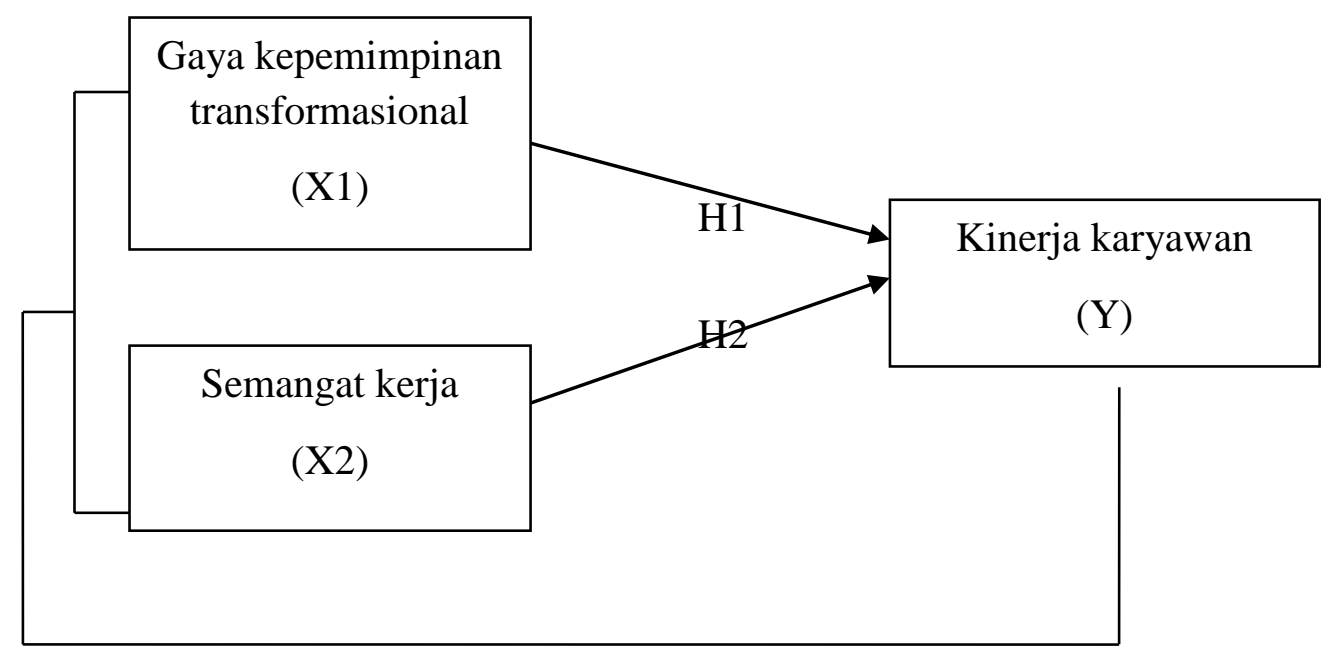

H3 (Simultan)

Gambar 2.1 Kerangka Penelitian

Sumber : Konsep yang dikembangkan dalam penelitian ini

\subsection{Definisi Oerasional}

Tabel 2.2

\begin{tabular}{|c|c|c|c|c|c|c|}
\hline \multirow{2}{*}{ No } & \multirow{2}{*}{ Variabel } & \multirow{2}{*}{$\begin{array}{c}\text { Definisi } \\
\text { Operasional }\end{array}$} & \multirow{2}{*}{ Dimensi } & \multicolumn{3}{|c|}{ Pengukuran variabel } \\
\hline & & & & Indikator & Alat ukur & Skala \\
\hline 1. & $\begin{array}{c}\text { Gaya } \\
\text { Kepemim } \\
\text { pinan } \\
\text { Transform } \\
\text { asional } \\
\text { (X1) }\end{array}$ & $\begin{array}{l}\text { Gaya } \\
\text { kepemimpinan } \\
\text { transformasional } \\
\text { adalah pemimpin } \\
\text { yang } \\
\text { menginspirasi } \\
\text { para pengikutnya } \\
\text { untuk } \\
\text { mengesampingka }\end{array}$ & $\begin{array}{l}\text { 1. Pengaruh } \\
\text { Ideal } \\
\text { 2. Motivasi } \\
\text { Inspirasi } \\
\text { 3. Stimulasi } \\
\text { Intelektual } \\
\text { 4. Pertimbang } \\
\text { an individu } \\
\text { Bass dan }\end{array}$ & $\begin{array}{l}\text { 1. Kharisma } \\
\text { 2. Motivasi } \\
\text { inspiratif } \\
\text { 3. Stimulasi } \\
\text { intelektual } \\
\text { 4. Perhatian } \\
\text { yang } \\
\text { individual } \\
\text { Robbins }\end{array}$ & Kuisioner & $\begin{array}{l}\text { Skala } \\
\text { Likert }\end{array}$ \\
\hline
\end{tabular}




\begin{tabular}{|c|c|c|c|c|c|c|}
\hline & & $\begin{array}{l}\mathrm{n} \text { kepentingan } \\
\text { pribadi mereka }\end{array}$ & $\begin{array}{l}\text { Avolio } \\
(2003)\end{array}$ & (2010:263) & & \\
\hline \multirow[t]{3}{*}{ No } & \multirow[t]{3}{*}{ Variabel } & \multirow{2}{*}{$\begin{array}{c}\text { Definisi } \\
\text { Operasional }\end{array}$} & \multirow{3}{*}{ Dimensi } & \multicolumn{3}{|c|}{ Pengukuran Variabel } \\
\hline & & & & Indikator & Alat ukur & Skala \\
\hline & & $\begin{array}{lr}\text { dan mereka } \\
\text { mampu memiliki } \\
\text { pengaruh luar } \\
\text { biasa pada diri } \\
\text { pengikutnya. }\end{array}$ & & & & \\
\hline 2. & $\begin{array}{c}\text { Semangat } \\
\text { Kerja } \\
\text { (X2) }\end{array}$ & $\begin{array}{lr}\text { Semangat } & \text { kerja } \\
\text { adalah melakukan } \\
\text { pekeIjaan secara } \\
\text { lebih } & \text { giat } \\
\text { sehingga dengan } \\
\text { demikian akan } \\
\text { dapat diharapkan } \\
\text { lebih cepat dan } \\
\text { lebih baik. }\end{array}$ & & $\begin{array}{l}\text { 1. Kegairahan } \\
\text { atau } \\
\text { antusiasme } \\
\text { (zeast,antuc } \\
\text { iasm) } \\
\text { 2. Kekuatan } \\
\text { untuk } \\
\text { melawan } \\
\text { frustasi } \\
\text { (resistance } \\
\text { of } \\
\text { frustration) } \\
\text { 3. Kualitas } \\
\text { untuk } \\
\text { bertahan } \\
\text { (staying } \\
\text { quality) } \\
\text { 4. Semangat } \\
\text { berkelompo } \\
\text { k (team } \\
\text { spirit) } \\
\text { Maier } \\
\text { (1998:135) }\end{array}$ & Kuisioner & $\begin{array}{l}\text { Skala } \\
\text { Likert }\end{array}$ \\
\hline
\end{tabular}




\begin{tabular}{|c|c|c|c|c|c|c|}
\hline 3. & $\begin{array}{c}\text { Kinerja } \\
\text { Karyawan } \\
\text { (Y) }\end{array}$ & $\begin{array}{l}\text { Kinerja } \\
\text { merupakan } \\
\text { kualitas dan } \\
\text { kuantitas dari }\end{array}$ & & $\begin{array}{l}\text { 1. Ketepatan } \\
\text { penyelesaia } \\
\text { n tugas } \\
\text { 2. Kesesuiaian } \\
\text { jam kerja } \\
\text { 3. Tingkat } \\
\text { Kehadiran }\end{array}$ & Kuisioner & $\begin{array}{l}\text { Skala } \\
\text { Likert }\end{array}$ \\
\hline \multirow{2}{*}{ No } & \multirow{2}{*}{ Variabel } & \multirow{2}{*}{$\begin{array}{c}\text { Definisi } \\
\text { Operasional }\end{array}$} & \multirow{2}{*}{ Dimensi } & \multicolumn{3}{|c|}{ Pengukuran variabel } \\
\hline & & & & Indikator & Alat ukur & Skala \\
\hline & & $\begin{array}{l}\text { suatu hasil } \\
\text { kerja(output) } \\
\text { individu maupun } \\
\text { kelompok dalam } \\
\text { suatu aktivitas } \\
\text { tertentu yang } \\
\text { diakibatkan oleh } \\
\text { kemampuan alami } \\
\text { atau kemampuan } \\
\text { yang diperoleh } \\
\text { dari proses belajar } \\
\text { serta keinginan } \\
\text { untuk berprestasi. }\end{array}$ & & $\begin{array}{l}\text { 4. Kerjasama } \\
\text { antar } \\
\text { karyawan } \\
\text { 5. Kepuasan } \\
\text { dalam } \\
\text { bekerja } \\
\text { Setiawan dan } \\
\text { kartika, } \\
\text { 2014:1447) }\end{array}$ & & $\begin{array}{l}\text { Skala } \\
\text { Likert }\end{array}$ \\
\hline
\end{tabular}

\subsection{Hipotesis Penelitian}

H1 : Diduga Gaya Kepempinan Transformasional berpengaruh signifikan terhadap kinerja karyawan Raffles City Hotel Bengkulu.

H2 : Diduga Semangat Kerja berpengaruh signifikan terhadap kinerja karyawan Raffles City Hotel Bengkulu.

H3 : Diduga Gaya Kepemimpinan Transformasional dan Semangat Kerja berpengaruh signifikan terhadap kinerja karyawan Raffles City Hotel Bengkulu. 


\section{BAB III \\ METODE PENELITIAN}

\subsection{Tempat dan Waktu Penelitian}

Penelitian ini dilakukan di Raffles City Hotel Jalan Pariwisata No.1 Pantai Panjang kota Bengkulu. Penelitian ini juli 2019 sampai dengan selesai.

\subsection{Jenis Penelitian}

Penelitian ini menggunakan jenis penelitian kuantitatif, karena penelitian ini disajikan dengan angka dan perhitungan menggunakan metode statistik. Menurut sugiyono (2016:28), data kuantitatif adalah data yang berbentuk angka atau data kualitatif yang diangkakan (scoring). Metode kuantitatif dapat diartikan sebagai metode penelitian yang berlangsung pada filsafat postivisme, digunakan untuk meneliti pada populasi atau sampel tertentu, pengumpulan data menggunakan instrument penelitian, analisis data bersifat kuantitatif/statistik, dengan tujuan untuk menguji hipotesis yang telah ditetapkan. Jenis penelitian kuantitatif ini lebih sistematis, terencana, terstruktur, jaelas dari awal hingga akhir penelitian. Metode penelitian kuantitatif ini disisi lain menyebutkan penelitian yang banyak menuntut penggunaan angka, mulai dari pengumpulan data, penafsiran terhadap data tersebut serta penampilan dari hasilnya yang telah diuji validitas dan reliabilitasnya.

Penelitian kuantitatif didasarkan pada perhitungan-perhitungan statistik sebagai dasar analisis. Penelitian dengan menggunakan pendekatan kuantitatif 
bertujuan untuk meneliti gejala populasi atau sampel tertentu dengan menggunakan instrumen penelitian sebagai pengumpulan data yang bersifat statistik dengan tujuan untuk menguji hipotesis yang telah ditetapkan.

\subsection{Populasi dan Sampel}

\subsubsection{Populasi}

Populasi adalah gabungan dari seluruh elemen yang berbentuk peristiwa, hal atau orang yang memiliki karateristik serupa yang menjadi pusat perhatian seorang peneliti karena itu dipandang sebagai sebuah penelitian (Ferdinand, 2006). Populasi dari penelitian ini adalah seluruh karyawan Raffles City Hotel Bengkulu yang berjumlah 31 orang. Apabila subyek penelitian berjumlah kurang dari 100, lebih baik diambil semua sehingga penelitiannya merupakan penelitian populasi (Arikunto, 2006:112), karena populasi penelitian ini hanya 31 orang, maka anggota populasi menjadi responden seluruhnya.

\subsubsection{Sampel}

Sampel merupakan bagian dari populasi yang menjadi unit pengamatan sabuah penelitian (Narimawati, 2008:73). Penelitian yang menggunakan seluruh anggota populasinya disebut sampel total(Total Sampling)atau sensus.Penggunaan metode ini berlaku jika anggota populasi relative kecil (mudah dijangkau). Dalam penelitian ini, karena jumlah populasi yang berjumlah 31 orang karyawan relative 
mudah dijangkau, maka penulis menggunakan metode total sampling. Dengan metode pengambilan sampel ini diharapkan dapat cenderung lebih mendekati nilai sesungguhnya dan diharapkan dapat memperkecil pula terjadinya kesalahan/penyimpangan terhadap nilai populasi Usman \& Akbar, (2008).

\subsection{Teknik Pengumpulan Data}

1. Observasi yaitu pengambilan data yang dilakukan pada awal penelitian, dengan tujuan untuk mendapatkan gambaran tentang keadaan, permasalahan penelitian ini.

2. Kuisioner merupakan suatu metode pengumpulan data dengan cara membuat daftar pertanyan atau angket siapkan terlebih dahulu kemudian diajukan kepada responden terpilih guna mendapatkan keterangan dan informasi dari responden yang bersangkutan. Dalam penelitian ini, kuisioner bersifat tertutup dimana hanya memilih alternatif jawaban yang tersedia di kuisioner.

Tabel 3.1

\section{Skala Likert}

\begin{tabular}{|l|l|c|}
\hline No & \multicolumn{1}{|c|}{ Alternatif jawaban } & Bobot nilai \\
\hline 1. & Sangat setuju (SS) & 5 \\
\hline 2. & Setuju (S) & 4 \\
\hline 3. & Netral (N) & 3 \\
\hline 4. & Tidak setuju (TS) & 2 \\
\hline 5 & Sangat tidak setuju (STS) & 1 \\
\hline
\end{tabular}

Sumber: Sugiyono (2013) 


\subsection{Uji Instrument Penelitian}

Kualitas data yang dihasilkan dari penggunaan instrument penelitian data dievakuasi melalui uji validitas dan reabilitas. Uji tersebut masing-masing untuk mengetahui konsistensi dan akurat data yang di kumpulkan dari penggunaan instrument kuesioner. Adapun uji instrument penelitian yang dimaksud adalah menguji validitas dan reabilitas yang di lakukan pada sampel uji ditentukan dengan sampel khusus sejumlah 20 orang responden yaitu diluar sampel penelitian.

\subsubsection{Uji Validitas}

Validitas menurut Sugiyono (2013) menunjukan derajat ketepatan antara data sesungguhnya yang terjadi pada objek dengan data yang dikumpulkan oleh peneliti. Untuk mencari validitas sebuah item, kita dapat mengkorelasikan skor item dengan total item tersebut, jika koefisien antara item dengan total item sama atau di atas 0.3 maka item tersebut dinyatakan valid, tetapi jika nilai korelasinya dinyatakan dibawah 0.3 maka dinyatakan nilai korelasinya tidak valid. Untuk mencari nilai koefisien, maka peneliti menggunakan rumus pearson product moment sebagai berikut :

$$
\mathbf{r}_{\mathbf{b}}=\frac{\boldsymbol{n}\left(\sum X Y\right)-\left(\sum X\right)\left(\sum Y\right)}{\sqrt{\left(\boldsymbol{n} \sum X^{2}-\left(\sum X\right)^{2}\right)\left(\boldsymbol{n} \sum y^{2}-\left(\sum Y\right)^{2}\right.}}
$$

Keterangan :

$\mathrm{r}_{\mathrm{b}}=$ Korelasi Product Moment

$\mathrm{N}=$ Banyaknya Pasangan Data $\mathrm{X}$ dan $\mathrm{Y}$ 


$$
\begin{aligned}
\Sigma \mathrm{X} & =\text { Jumlah Dari Variabel } \mathrm{X} \\
\Sigma \mathrm{Y} & =\text { Jumlah Dari Variabel } \mathrm{Y} \\
\Sigma \mathrm{X}^{2} & =\text { Jumlah Kuadrat Total Dari Variabel } \mathrm{Y} \\
\Sigma \mathrm{Y}^{2} & =\text { Jumllah Kuadrat Total Dari Variabel } \mathrm{X} \\
\Sigma \mathrm{XY} & =\text { Jumlah Perkalian Total Variabel } \mathrm{X} \text { dan } \mathrm{Y}
\end{aligned}
$$

Tabel 3.2

\section{Hasil Uji Validitas}

\begin{tabular}{|c|c|c|c|}
\hline Variabel & Pernyataan & $\begin{array}{c}\text { Corrected Item } \\
\text { Pernyataan } \\
\text { Total } \\
\text { Correlation }\end{array}$ & Kesimpulan \\
\hline Gaya Kepemimpinan & 1 & 0,786 & \\
\cline { 2 - 4 } Transformasional & 2 & 0,732 & Valid \\
\cline { 2 - 4 } & 3 & 0,709 & Valid \\
\cline { 2 - 4 } & 4 & 0,671 & Valid \\
\hline Semangat Kerja & 5 & 0,856 & Valid \\
\cline { 2 - 4 } & 6 & 0,844 & Valid \\
\cline { 2 - 4 } & 7 & 0,661 & Valid \\
\cline { 2 - 4 } & 8 & 0,837 & Valid \\
\hline Kinerja Karyawan & 9 & 0,662 & Valid \\
\cline { 2 - 4 } & 10 & 0,712 & Valid \\
\cline { 2 - 4 } & 11 & 0,654 & Valid \\
\cline { 2 - 4 } & 12 & 0,694 & Valid \\
\cline { 2 - 4 } & 13 & 0,729 & \\
\hline
\end{tabular}

Sumber: Hasil Uji Coba Validitas data diolah, 2019.

Berdasarkan tabel 3.2 yakni hasil uji validitas Dari tabel diatas dapat dilihat bahwa nilai Corrected Item Pernyataan Total Correlation menunjukkan nilai lebih 
dari 0,3, Ini menunjukkan bahwa item dari setiap variabel tersebut adalah valid dan layak untuk digunakan dalam penelitian ini.

\subsubsection{Uji Reliabilitas}

Reliabilitas/keandalan (derajat konsistensi) adalah ukuran yang menunjukkan seberapa tinggi suatu instrument dapat dipercaya atau dapat diandalkan, artinya reliabilitas menyangkut ketepatan (dalam pengertian konsisten) alat ukur Onsardi (2018). Reliabilitas merupakan konsistensi atau kestabilan skor suatu instrument penelitian terhadap individu yang sama, dan diberikan dalam waktu yang berbeda. Reliabilitas sebagai suatu perkiraan tingkatan (dagree) konsistensi atau kestabilan antara pengukuran ulangan dan pengukuran pertama dengan menggunakan instrument yang sama (Wrightstone dalam Asmawi, M. (2017)). Alat untuk mengukur reliabilitas adalah alpha cronbach, suatu variabel dikatakan reliabel, apabila ( iman Ghozali dalam Yasha Aulia. 2016:41):

Hasil Alpha Cronbach > 0,60 = reliabel

Hasil Alpha Cronbach $<0.60=$ tidak reliable

Rumus spearman brown:

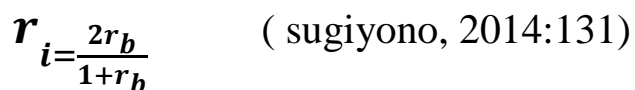

$$
\begin{aligned}
& r_{i}=\text { reliabilitas internal seluruh instrument } \\
& r_{b}=\text { korelasi product moment antar belahan pertama dan kedua }
\end{aligned}
$$


Tabel 3.3

\section{Hasil Uji Reliabilitas}

\begin{tabular}{|c|c|c|c|c|}
\hline No & Variabel & Pernyataan & $\begin{array}{c}\text { Cronbac's } \\
\text { Alpha }\end{array}$ & Kesimpulan \\
\hline 1 & $\begin{array}{c}\text { Gaya Kepemimpinan } \\
\text { Transformasional }\end{array}$ & 4 & 0,668 & Reliabel \\
\hline 2 & Semangat Kerja & 4 & 0,812 & Reliabel \\
\hline 3 & Kinerja Karyawan & 5 & 0,726 & Reliabel \\
\hline
\end{tabular}

Sumber: Hasil Uji Coba Reliabilitas data diolah, 2019.

Dari hasil uji reliabilitas yang dilakukan dengan menggunakan program statistic SPSS maka diperoleh cronbah's alpha lebi besar dari 0,60 untuk ketiga variabel yaitu: Gaya Kepemimpinan Transformasional, Semangat Kerja, dan Kinerja Karyawan. Oleh karena itu, semua item pernyataan kuesioner dapat digunakan dalam penelitian ini.

\subsection{Teknik Analsis Data}

Teknik analisa data merupakan suatu langkah yang paling menentukan dari suatu penelitian, karena analisa data berfungsi untuk menyimpulkan hasil penelitian. Berikut beberapa teknik analisa data yang peneliti gunakan dalam penelitian ini:

\subsubsection{Uji Asumsi Klasik}

Uji Asumsi Klasik yang digunakan dalam pemelitian ini adalah: 


\section{Uji Normalitas}

Uji normalitas digunakan untuk melihat tingkat kenormalan data yang digunakan, apakah data berdistribusi normal atau tidak. Tingkat kenormalan data sangat penting, karena data yang berdistribusi normal dianggap dapat mewakili populasi dalam penelitian. Kriteria pengambilan keputusan dalam uji normalitas menurut Priyatno (2010) yaitu:

1. Jika data menyebar disekitar garis diagonal dan mengikuti arah garis diagonal, maka model regresi memenuhi asumsi normalitas.

2. Jika data menyebar jauh dan garis diagonal dan atau tidak mengikuti arah garis diagonal, maka model asumsi normalitas tidak memenuhi uji asumsi normalitas.

\section{Uji Multikolinieritas}

Uji multikoliniearitas bertujuan untuk menguji apakah model regresi ditemukan adanya korelasi antara variabel bebas (independen). Model regresi yang baik sebaiknya tidak terjadi korelasi di antara variabel independen (Ghozali, 2011: 105). Salah satu alat untuk mendeteksi ada atau tidaknya multikolinieritas di dalam model regresi adalah dengan melihat nilai tolerance dan lawannya serta nilai Variance Inflation Faktor (VIF). Tolerance mengukur variabilitas variabel independen yang terpilih yang tidak di jelaskan oleh variabel dependen lainnya. Nilai 
cutoff yang umum dipakai untuk menunjukkan adanya multikolinieritas adalah nilai tolerance $=0,10$ atau sama dengan nilai $\mathrm{VIF}=10$.

\section{Uji Heteroskedastisitas}

Uji Heteroskedastisitas adalah varian residual yang tidak sama ada semua pengamatan di dalam model regresi dimana regresi yang baik seharusnya tidak terjadi heteroskedastisitas (Priyatno,2010). Pengambilan keputusan yaitu dengan cara:

1. Jika ada pola tertentu, seperti titik-titik yang ada membentuk suatu pola tertentu yang teratur (bergelombang melebar kemudian menyempit), maka terjadi heteroskedastisitas.

2. Jika tidak ada pola yang jelas, seperti titik-titik yang menyebar di atas dan di bawah angka 0 pada sumbu Y, maka tidak terjadi heteroskedastisitas. Dari output regresi titik-titiktidak membentuk pola yang jelas, dan titik-titik menyebar di atas dan di bawah angka 0 pada sumbu Y, jadi dapat disimpilkan bahwa tidak terjadi heteroskedastisitas dalam model regresi

\subsubsection{Analisis Deskriptif Kuantitatif}

Statisik deskriptif adalah statistik yang digunakan untuk menganalisis data dengan cara mendiskripsikan data yang telah dikumpul sebagaimana adanya tanpa bermaksud membuat kesimpulan yang berlaku umum atau generalisasi. Statistik deskriptif digunakan untuk mendiskripsikan data sampel, yang termasuk kedalam statistik deskriptif antara lain, penyajian data melalui table, grafik, diagram, 
perhitungan modus, median, mean, perhitungan penyebaran data melalui rata-rata dan standar deviasi, serta perhitungan persentase.

Analisis deskriptif digunakan untuk mengambil fenomena yang terjadi dilapangan berdasarkan variabel-variabel penelitian pengamatan dan persepsi responden terhadap variabel yang digunakan dalam penelitian ini digunakan metode penghitungan rata-rata di gunakan rumus (sugiyono.2010).

$\bar{X}=\frac{\sum x}{N}$

Dimana

$\bar{X} \quad=$ Angka Rata-rata

$\sum \mathrm{x}=$ Jumlah Responden

$\mathrm{N} \quad=$ Nilai Responden

Selanjutnya di hitug juga skala interval jawaban responden yang bertujuan untuk memudahkan interperensi hasil dengan rumus (sugiyono. 2010).

Skala interval $=\frac{\mathrm{U}-\mathrm{L}}{\mathrm{k}}$

Dimana

$\mathrm{U}=$ Skor jawaban tertinggi

$\mathrm{L}=$ Skor jawaban terendah

$\mathrm{K}=$ Jumlah kelas interval 
Dari rumus di atas maka skala interval yang di gunakan dalam penelitian ini adalah:

Dik. Skor jawaban tertinggi $(\mathrm{U})=5$

Skor jawaban terendah $(\mathrm{L})=1$

Jumlah kelas interval $(\mathrm{k})=5$

Skala interval $=\frac{5-1}{5}=\frac{4}{5}=0,80$

Jadi jarak tiap skala interval adalah sebesar 0,80

Dari skala interval tersebut, selanjutnya diinterkenerjakan ke dalam rata-rata jawaban responden dengan criteria sebagai berikut:

Tabel 3.4

Kriteria Penilaian Tanggapan Responen

\begin{tabular}{|c|c|c|}
\hline No & Skala & Skor per Variabel \\
\hline 1 & $1,00-1,80$ & Sangat Tidak Baik \\
\hline 2 & $1,81-2,60$ & Tidak Baik \\
\hline 3 & $2,61-3,40$ & Kurang Baik \\
\hline 4 & $3,41-4,20$ & Baik \\
\hline 5 & $4,21-5,00$ & Sangat Baik \\
\hline
\end{tabular}

(Sugiyono, 2010).

\subsubsection{Analisis Regresi Linear Berganda}

Analisis kuantitatif dengan menggunakan alat analisis regresi linier berganda adalah suatu analisis yang digunakan oleh peneliti, bila peneliti bermaksud 
meramalkan bagaimana keadaan (naik turunnya) variabel dependen, bila dua variabel atau lebih variabel sebagai faktor prediktor, sebagaimana dikutip dari (Sugiyono, $2013: 192)$

Persamaan regresi tersebut adalah sebagai berikut:

$$
Y=a+b 1 \times 1+b 2 \times 2+e
$$

Dimana:

$\mathrm{Y} \quad=$ Variabel Dependen (Kinerja Karyawan)

a $\quad=$ Kostanta

b1-b2 = Koefisien Regresi

$\mathrm{X} 1-\mathrm{X} 2$ = Variabel Independen (Gaya Kepemimpinan dan Semangat Kerja)

e $\quad=$ error

Namun untuk memudahkan analisis regresi ganda maka peneliti menggunakan program SPSS dalam pengolahan data.

\subsection{Koefisen Determinasi $\left(R^{2}\right)$}

Koefisien Determinasi $\left(\mathrm{R}^{2}\right)$ pada intinya digunakan untuk mengukur seberapa jauh kemampuan model regresi dalam menerangkan variasi variabel dependen (Ghozali, 2009). Penelti menggunakan adjusted $\mathrm{R}^{2}$ untuk mengeveluasi mana model regresi terbaik. Nlai $\mathrm{R}^{2}$ dapat naik atau turun apabila suatu variabel independen di tambah kedalam model.

Koefisien determinasi $\left(\mathrm{R}^{2}\right)$ dinyatakan dalam persentase yang nilainya berkisar antara $0<\mathrm{R}^{2}<1$. Nilai $\mathrm{R}^{2}$ yang kecil berarti kemampuan variabel-variabel 
independen dalam menjelaskan variasi variabel dependen amat terbatas. Nilai yang mendekati satu berarti variabel-variabel independen memberikan hampir semua informasi yang dibutuhkan untuk memprediksi variasi variabel dependen.

\subsection{Pengujian Hipotesis}

\subsubsection{Uji t (Uji Parsial)}

Uji t yaitu suatu uji untuk mengetahui signifikansi pengaruh variabel bebas secara parsial atau individual menerangkan variabel terikat (Ghozali, dalam adi wahyu nugroho, 2013:8). Hasil untuk uji t semua variabel (Gaya Kepemimpinan Tranformasional dan Semangat Kerja) mempunyai hasil t hitung yang lebih besar dari pada t table dengan signifikan di bawah 0,05. Karena nilai signifikan $<0,05$ maka H0 ditolak dan Ha diterima. Dengan demikian jika kedua variabel Gaya Kepemimpinan Transformasional dan Semangat Kerja maka akan meningkatkan variabel Kinerja Karyawan

Hipotesis dirumuskan sebagai berikut:

$\mathrm{HO}: \mathrm{bi}=0$

$\mathrm{Ha}: \mathrm{bi} \neq 0$

Ketentuan dalam pengujian ini adalah sebagai berikut:

1) Jika tingkat signifikan $\leq 5 \%$, H0 ditolak dan Ha diterima

Jika tingkat signifikat $\geq 5 \%, \mathrm{H} 0$ diterima dan Ha ditolak 


\subsubsection{Uji F (Simultan)}

Uji F pada dasar meunjukkan apakah semua variabel independen (X) atau bariabel bebas secara bersama-sama dapat berpengaruh terhadap variabel dependen (Y) (Ghozali, dalam adi wahyu nugroho, 2013:8). Hasil untuk uji t semua variabel (Gaya Kepemimpinan Trasnformasional dan Semangat Kerja) mempunyai hasil t hitung yang lebih besar dari pada t table dengan signifikan di bawah 0,05. Karena nilai signifikan $<0,05$ maka yang berarti model regresi dapat dikatakan fit atau baik.

1) Menentukan hipotesis nol maupun hipotesis alternatifnya:

$\mathrm{H} 0: \mathrm{bi}=\mathrm{b} 2=\mathrm{b} 3=0$, berarti tidak ada pengaruh $\mathrm{X} 1, \mathrm{X} 2$, terhadap $\mathrm{Y}$

$\mathrm{Ha}: \mathrm{b} 1 \neq \mathrm{b} 2 \neq \mathrm{b} 3 \neq 0$, berarti ada pengaruh $\mathrm{X} 1, \mathrm{X} 2$, terhadap $\mathrm{Y}$

2) Membuat keputusan uji $\mathrm{F}$ jika nilai $\mathrm{F}$ lebih besar dari pada 4 maka $\mathrm{H} 0$ ditolak pada derajat kepercayaan 5\%, dengan kata lain hipotesis alternatif (Ha) diterima, yang menyatakan bahwa semua variabel independen secara serentak dan signifikan mempengaruhi variabel dependen. 


\section{BAB IV \\ HASIL DAN PEMBAHASAN}

\subsection{Sejarah Singkat Raffles City Hotel Bengkulu}

Awal berdirinya Raffles City Hotel Bengkulu pada tahun 2007 milik pemda kota yang di kelola oleh swasta (PT. Batu Keris Kepahiang). Awalnya Raffles City Hotel Bengkulu tersebut belum langsung ingin di bangun menjadi sebuah hotel melainkan ingin di bangun menjadi MES, namun di pegang oleh pihak ketiga oleh pihak ktiga tersebutlah yang merencanakan pembangunan hotel dan disinilah awal mula Raffles City Hotel Bengkulu di bangun, Raffles City Hotel merupakan hotel milik swasta bukan milik pribadi, Raffles City Hotel tersebut milik pemda kota dan di operasikan oleh Manajer salah satunya Ibu Mardalena yang beroperasi sebagai Operational Manager.

Raffles City Hotel di bangun dengan total 32 kamar, 2 ballroom, 1 restaurant dan swimming pool, Seiring berjalannya waktu Raffles City Hotel Bengkulu terus mendapatkan dan dilakukan perubahan seperti terdapat lapangan tennis yang terletak di dekat taman hotel, dan terdapat juga taman yang terpapar luas di depan halaman kamar-kamar hotel, dan juga terdapat mushola terletak di dekat kamar hotel sehingga mudah di jangkau oleh tamu yang bermalaman di hotel tersebut. Raffles City Hotel Bengkulu berada di J1. Pariwisata No. 1, Pantai Panjang, Bengkulu. Merupakan hotel berkualitas setara bintang 2 yang berselang 5 menit berkendara dari pusat kota. Hotel 
dengan bangunan tempo dulu namun memiliki kesan dan pesan tradisional bagi tamu yang bermalam di Raffles City Hotel. Raffles City Hotel Bengkulu memiliki akses yang strategis, dekat dengan beragam tempat menarik, diataranya pantai panjang, BIM dan Mega Mall.

\subsection{Struktur Organisasi Raffles City Hotel Bengkulu}

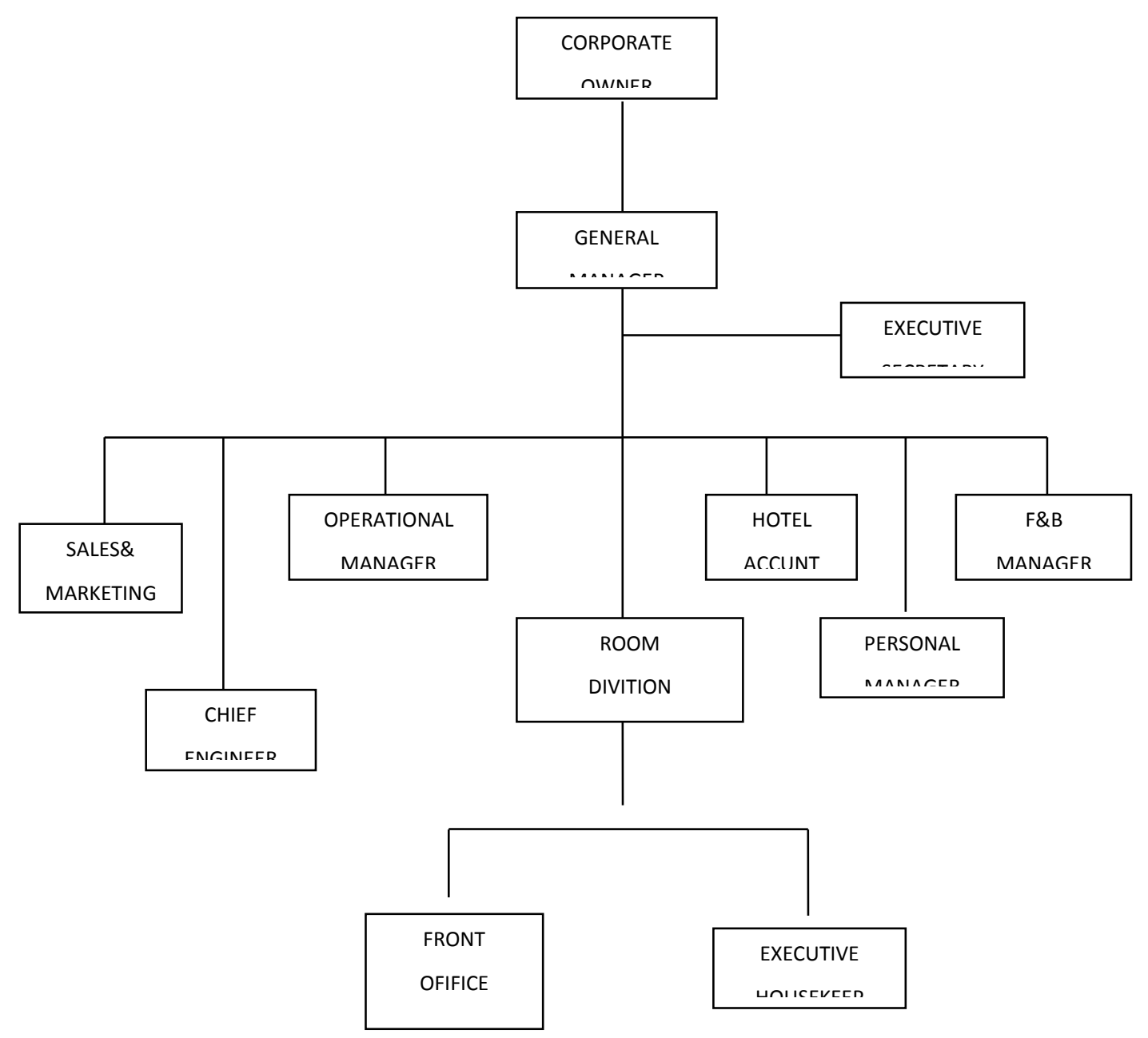

Gambar 4.1

Struktur Organisasi 


\section{Corporate Owner}

Komisaris atau pemilik Raffles City Hotel Bengkulu

\section{General Manager}

Direktur atau pimpinan tertinggi dalam perusahaan yang mengatur semua urusan yang berkaitan dengan berjalannya perusahaan baik didalam maupun diluar.

3. Executive Secretary

Sekretaris direktur utama yang mengatur semua jadwal kegiatan atau acara.

\section{Sales dan Marketing}

Bagian yang bertugas mempromoasikan hotel

\section{Operational Manager}

Sebagai control penuh dari pengoperasian hotel tersebut sesuai standar yang telah ditetapkan.

\section{Hotel Account}

Yang bertanggungjawab mengendalikan segala operasional keuangan yang ada didalam hotel.

7. F \& B Manager 
Yang menggantungkan dari penjualan makanan dan minuman.

\section{Chief Engineer}

Memiliki tugas dan tanggung jawab melakukan perbaikan-perbaikan.

\section{Room Divition Manager}

Yang bertugas mempersiapkan kamar.

10. Personal Manager

Yang memiliki tugas dan tanggung jawab melakukan perencannan, pengawasan, perekrutan karyawan.

11. Front Office Manager

Yang bertugas mengurusi registrasi tamu

12. Executive Housekeep

Yang memiliki tugas dan tanggung jawab menyiapkan kamar bagi para tamu serta membersihkannya selama tamu menginap di hotel tersebut.

\subsection{Uji asumsi klasik}

\subsubsection{Uji Normalitas}

Uji normalitas bertujuan untuk menguji apakah dalam model regresi, variabel pengganggu atau residual memilki distribusi normal. Uji normalitas dalam penelitian ini menngunakan plot. Adapun hasil uji dapat dilihat pada tabel dibawah ini: 


\section{Gambar 4.2}

\section{Hasil Uji Normalitas}

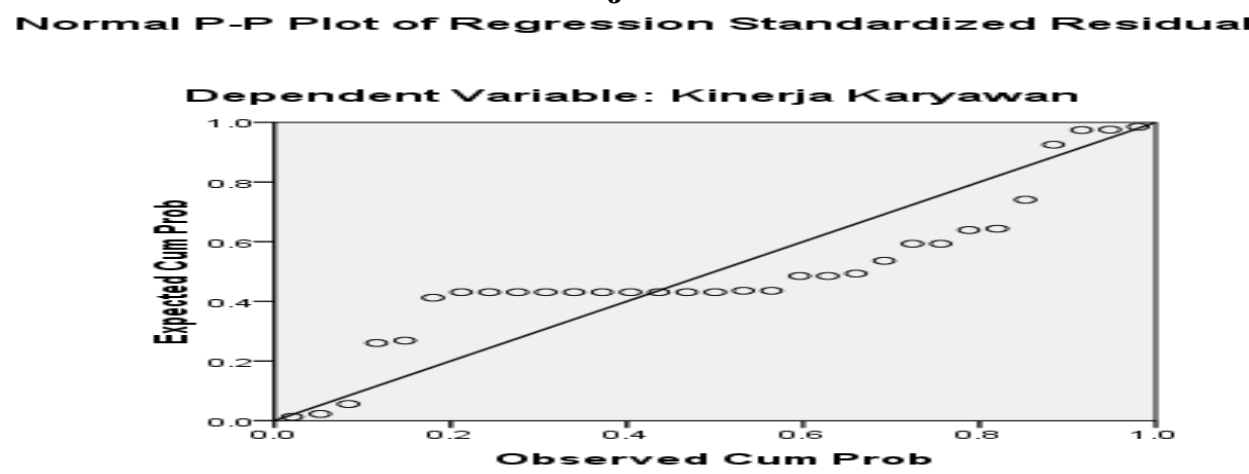

Sumber: Hasil olah data 2019

Berdasarkan gambar 4.2 menunjukkan bahwa titik-titik menyebar di bawah dan di atas 0 pada sumbu Y. Maka, dapat disimpulkan bahwa variebel berdistribusi normal.

\subsubsection{Uji Multikolinieritas}

Uji multikolinieritas bertujuan untuk menguji apakah model regresi ditemukan adanya korelasi antara variabel bebas. Model regresi yang baik sebaiknya tidak terjadi korelasi diantara varibel bebas. Berikut hasil uji multikolinieritas:

Tabel 4.2

\section{Hasil Uji Multikolinieritas}

Coefficients $^{\mathrm{a}}$

\begin{tabular}{|l|c|c|c|c|c|c|c|}
\hline \multirow{2}{*}{ Model } & \multicolumn{2}{|c|}{$\begin{array}{c}\text { Unstandardized } \\
\text { Coefficients }\end{array}$} & $\begin{array}{c}\text { Standardized } \\
\text { Coefficients }\end{array}$ & & \multicolumn{2}{|c|}{$\begin{array}{c}\text { Collinearity } \\
\text { Statistics }\end{array}$} \\
\cline { 2 - 4 } & B & Std. Error & Beta & T & Sig. & Tolerance & VIF \\
\hline
\end{tabular}




\begin{tabular}{|l|r|r|r|r|r|r|r|}
\hline $1 \quad$ (Constant) & 7.175 & 2.440 & & 2.941 & .007 & & \\
Gaya Kepemimpinan & .396 & .173 & .350 & 2.284 & .030 & .560 & 1.785 \\
Transformasional & .512 & .151 & .519 & 3.387 & .002 & .560 & 1.785 \\
\hline
\end{tabular}

a. Dependent Variable: Kinerja Karyawan

Sumber: Hasil olah data 2019

Berdasarkan tabel 4.2 menunjukkan bahwa nilai tolerance lebih besar dari 0,10 dan nilai VIF lebih kecil dari 10. Jadi dapat disimpulkan bahwa tidak terjadi multikolinieritas.

\subsubsection{Uji Heteroskedastisitas}

Uji heteroskedastisitas adalah varian residual yang tidak sama, dimana regresi yang baik seharusnya tidak terjadi heteroskedasitas. Berikut hasil uji heteroskedastisitas: 


\section{Gambar 4.3}

\section{Hasil Uji Heteroskedastisitas}

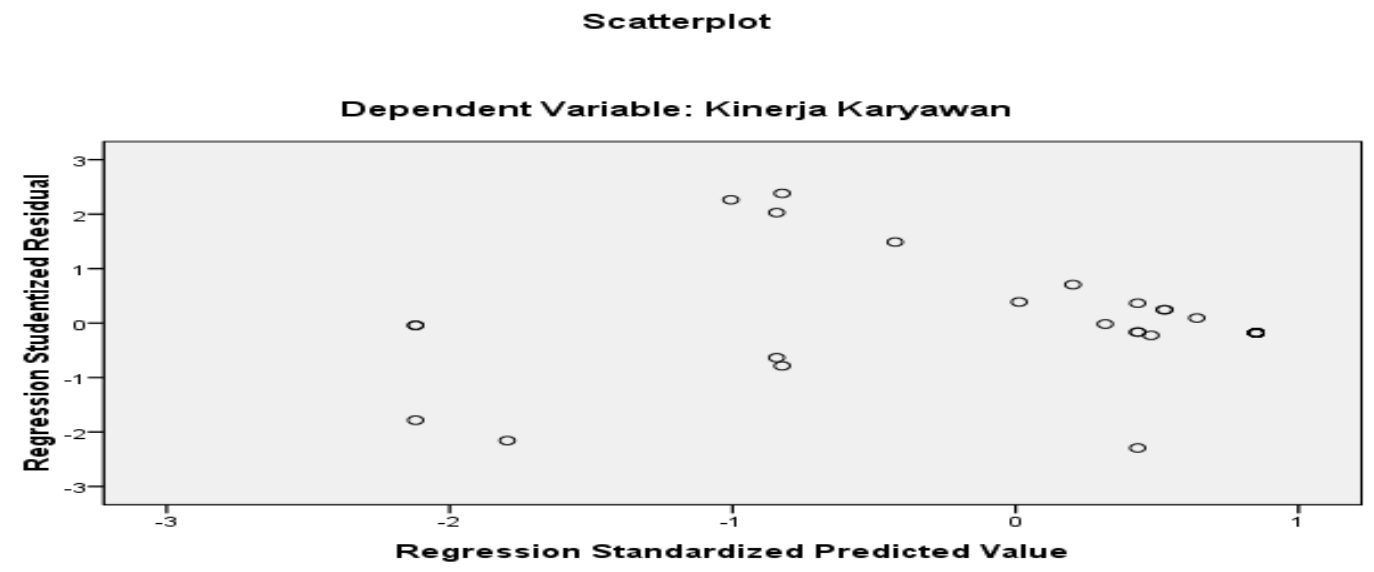

Sumber: Hasil olah data 2019

Berdasarkan gambar 4.3 di atas menunjukkan bahwa titik menyebar di atas dan di bawah angka 0 pada sumbu Y. Jadi dapat disimpulkan tidak terjadi heteroskedastisitas.

\subsection{Analisi Deskriptif}

\subsubsection{Karakteristik Responden}

Adapun karakteristik responden yang digunakan dalam penelitian ini adalah Karyawan yang bekerja di Raffles City Hotel Bengkulu sebanyak 31 orang. Lebih jelasnya dapat diuraikan sebagai berikut:

\subsubsection{Karakteristik Responden Berdasarkan Umur}


Hasil penelitian yang dilakukan terhadap 31 karyawan yang bekerja di Raffles City Hotel Bengkulu, diperoleh karakteristik responden berdasarkan tingkat usia, Adapun karakteristik responden berdasarkan usia atau umur dapat disajikan pada tabel dibawah ini:

Tabel 4.3

Karakteristik Responden Berdasarkan Umur

\begin{tabular}{|c|c|c|c|}
\hline No & Usia (Tahun) & Jumlah Responden (Orang) & Presentase (\%) \\
\hline 1 & $<20$ & 0 & $0 \%$ \\
\hline 2 & $21-30$ & 13 & $41.93 \%$ \\
\hline 3 & $31-40$ & 10 & $32.26 \%$ \\
\hline 4 & $41-50$ & 8 & $25.81 \%$ \\
\hline 5 & $>50$ & 0 & 100.00 \\
\hline & Jumlah & 31 & $0 \%$ \\
\hline
\end{tabular}

Sumber: Hasil olah data 2019

Berdasarkan Tabel 4.3 menunjukkan bahwa responden dalam penelitian ini berusia antara $<20$ sebanyak 0 orang $0(\%)$, selanjutnya Responden yang berusia 21 30 Tahun berjumlah 13 orang 41,93 (\%), yang berusia 31-40 tahun sebanyak 10 orang 32,26 (\%), yang berusia 41-50 tahun sebanyak 8 orang 25,81 (\%), dan yang berusia $>50$ tahun sebanyak 0 orang $0(\%)$. Oleh karena itu, keseluruhan Responden (100\%). dan didominasi kategori umur dewasa untuk dapat memberikan penilaian dan jawaban atas pertanyaan yang diberikan kepada mereka. Kesimpulan dari data di atas adalah jumlah responden yang paling banyak yaitu berumur 21-30 sebanyak 13 
orang usia dewasa hal tersebut menunjukkan bahwa karyawan yang bekerja di Raffles City Hotel Bengkulu produktivitas kerjanya pada usia dewasa yang sangat produktivitas dalam melakukan pekerjaan di Raffles City Hotel Bengkulu.

\subsubsection{Karakteristik Responden Berdasarkan Jenis Kelamin}

Berdasarkan data yang masuk dapat terlihat bahwa responden yang ditemui terdiri dari laki-laki dan perempuan yang Raffles City Hotel Bengkulu. Adapun karakteristik responden berdasarkan jenis kelamin dapat disajikan pada tabel berikut:

\section{Tabel 4.4}

\section{Karakteristik Responden Berdasarkan Jenis Kelamin}

\begin{tabular}{|c|c|c|c|}
\hline No & Jenis Kelamin & Jumlah Responden (Orang) & Presentase $(\%)$ \\
\hline 1 & Laki-Laki & 17 & $54.84 \%$ \\
\hline 2 & Perempuan & 14 & $45.16 \%$ \\
\hline & Jumlah & 31 & 100.00 \\
\hline
\end{tabular}

Sumber: Hasil olah data 2019

Berdasarkan pada Tabel 4.4 dapat diketahui bahwa responden penelitian yang berjenis kelamin laki-laki berjumlah 17 orang atau 54,84\% yang bekerja di Raffles City Hotel Bengkulu, sedangkan perempuan berjumlah 14 orang atau 45,16\%. Hal ini menunjukkan bahwa jumlah karyawan yang lebih banyak bekerja di Raffles City Hotel Bengkulu adalah laki-laki. 


\subsubsection{Tanggapan Responden Terhadap Variabel Penelitian}

Adapun tanggapan responden yang digunakan dalam penelitian ini adalah jawaban responden, karyawan yang bekerja di Raffles City Hotel Bengkulu sebanyak 31 orang. Lebih jelasnya dapat diuraikan sebagai berikut:

\subsubsection{Tanggapan Responden Terhadap gaya kepemimpinan transformasional}

Pada Variabel Gaya Kepemimpinan Transformasional, penilaian dilakukan 4 indikator, yaitu: Kharisma, Motivasi Inspiratif, Stimulasi Intelektual, Perhatian yang Individual. Adapun tanggapan responden terhadap variabel Gaya Kepemimpinan Transformasional dalam penelitian ini dapat dilihat pada tabel berikut:

Tabel 4.5

\section{Tanggapan Responden Terhadap Gaya Kepemimpinan Transformasional}

\begin{tabular}{|c|l|c|c|c|c|c|c|}
\hline No & \multicolumn{1}{|c|}{ Pernyataan } & STS & TS & N & S & SS & Rata \\
\hline & Gaya Kepemimpinan Transformasional & \multicolumn{4}{|l|}{} & \\
\hline 1. & $\begin{array}{l}\text { Atasan saya menyampaikan visi dan misi } \\
\text { yang jelas kepada karyawannya }\end{array}$ & - & - & 6 & 5 & 20 & 4,45 \\
\hline 2. & $\begin{array}{l}\text { Atasan saya mampu membangkitkan } \\
\text { semangat kerja para karyawannya }\end{array}$ & - & - & 5 & 3 & 23 & 4,58 \\
\hline 3. & $\begin{array}{l}\text { Atasan saya dapat mendukung kreativitas } \\
\text { dalam bekerja }\end{array}$ & - & - & 5 & 2 & 24 & 4,61 \\
\hline 4. & $\begin{array}{l}\text { Atasan saya mampu meningkatkan } \\
\text { prestasi karyawannya dengan memberi } \\
\text { perhatian terhadap waktu kerja }\end{array}$ & - & 7 & 2 & 22 & 4,48 \\
\hline & & & & \\
\hline
\end{tabular}

Sumber : Hasil olah data 2019 
Berdasarkan tabel 4.5 dapat diketahui rata-rata jawaban responden untuk variabel Gaya Kepemimpinan Transformasional sebesar 4,53. Nilai ini menunjukkan tanggapan responden atas variabel Gaya Kepemimpinan Transformasional berada pada kriteria sangat baik. Hasil tanggapan responden yang paling tinggi adalah Atasan dapat mendukung kreativitas dalam bekerja dengan rata-rata sebanyak 4,61 hal tersebut menunjukkan bahwa dalam kinerja perusahaan tentunya dukungan atasan memang sangatlah penting untuk meningkatkan kreativitas dalam bekerja, dengan adanya dukungan oleh atasan karyawan tersebut akan lebih bersemangat dalam bekerja dan tentunya akan meningkatkan kinerja karyawan.

Hasil tanggapan yang paling rendah adalah dengan pernyataan. Atasan menyampaikan visi dan misi yang jelas kepada karyawannya dengan rata-rata sebesar 4,45 Hal tersebut menunjukkan bahwa masih minimnya atasan menyampaikan visi dan misi kepada karyawan, seharusnya atasan lebih jelas untuk menyampaikan persepsi dari tujuan perusahaan, guna untuk agar karyawan lebih mengerti akan tujuan perusahaan tersebut.

\subsubsection{Tanggapan Responden Terhadap Semangat Kerja}

Pada variabel Semangat Kerja, penilaian dilakukan 4 indikator, yaitu: Kegairahan atau antusiasme, Kekuatan untuk melawan frustasi, Kualitas untuk bertahan, Semangat berkelompok. Adapun tanggapan responden terhadap variabel Semangat Kerja dalam penelitian ini dapat dilihat pada tabel berikut: 
Tabel 4.6

Tanggapan Responden Terhadap Semangat Kerja

\begin{tabular}{|c|l|c|c|c|c|c|c|}
\hline No. & Pernyataan & STS & TS & N & S & SS & Rata \\
\hline Semangat Kerja & \multicolumn{5}{|l|}{} & \multicolumn{4}{|c|}{} \\
\hline 1. & Saya selalu bersemangat dalam bekerja & - & - & 8 & 2 & 21 & 4,42 \\
\hline 2. & $\begin{array}{l}\text { Ketika saya mengalami kegagalan dalam } \\
\text { bekerja, saya akan segera memperbaikinya }\end{array}$ & - & - & 7 & 3 & 21 & 4,45 \\
\hline 3. & $\begin{array}{l}\text { Saya tetap bertahan setiap mengalami } \\
\text { kesulitan dalam bekerja }\end{array}$ & - & - & 11 & 2 & 18 & 4,23 \\
\hline 4. & $\begin{array}{l}\text { Saya dan rekan saya saling membantu } \\
\text { agar pekerjaan dapat terselesaikan dengan } \\
\text { baik } \\
\text { Rata-Rata }\end{array}$ & - & 10 & 2 & 19 & 4,29 \\
\hline
\end{tabular}

Sumber : Hasil olah data 2019

Berdasarkan tabel 4.6 dapat diketahui rata-rata jawaban responden untuk variabel Semangat Kerja sebesar 4,34. Nilai ini menunjukkan tanggapan responden atas variabel Semangat Kerja berada pada kriteria sangat baik. Hasil tanggapan responden berdasarkan variabel Semangat Kerja pernyataan yang paling tinggi adalah ketika mengalami kegagalan dalam bekerja saya akan segera memperbaikinya dengan rata-rata sebanyak 4,45 hal tersebut menunjukkan bahwa pada saat mengalami kegagalan dalam bekerja karyawan cepat mencari apa masalah dari kegagalan tersebut dan segera memperbaikinya agar kinerja perusahaan dapat berjalan dengan baik dan kinerja karyawan semakin berkembang.

Hasil tanggapan paling rendah adalah dengan pernyataan saya tetap bertahan setiap mengalami kesulitan dalam bekerja dengan rata-rata sebanyak 4,23 hal tersebut menunjukkan bahwa ada masanya karyawan tersebut merasakan tuntutan kerja yang 
sulit dalam perusahaan, dan hal itu lebih baik di konsultasikan oleh atasan lebih dahulu bahwasanya tuntutan kerja yang dialami terlalu sulit, karena karyawan juga perlu merasakan kepuasan dalam menjalani kerja tersebut agar semakin bersemangat dalam bekerja dan tentunya akan meningkatkan kinerja karyawan.

\subsubsection{Tanggapan Responden Terhadap Kinerja Karyawan}

Pada variabel Kinerja karyawan penilaian dilakukan 5 indikator, yaitu: Ketepatan penyelesaian tugas, Kesesuian jam kerja, Tingkat kehadiran, Kerjasama antar karyawan, Kepuasan dalam bekerja. Adapun tanggapan responden terhadap variabel Kinerja Karyawan dalam penelitian ini dapat dilihat pada tabel berikut:

Tabel 4.7

Tanggapan Responden Terhadap Kinerja Karyawan

\begin{tabular}{|c|l|c|c|c|c|c|c|}
\hline No & \multicolumn{1}{|c|}{ Pernyataan } & STS & TS & N & S & SS & Rata \\
\hline & Kinerja Karyawan & \multicolumn{5}{|l|}{} & \multicolumn{1}{|l|}{} \\
\hline 9. & $\begin{array}{l}\text { Saya menyelesaikan tugas yang diberikan } \\
\text { dengan tepat waktu }\end{array}$ & - & 1 & 2 & 7 & 21 & 4,55 \\
\hline 10. & $\begin{array}{l}\text { Saya bekerja sesuai dengan jam kerja } \\
\text { yang ditetapkan }\end{array}$ & - & - & 4 & 4 & 23 & 4,61 \\
\hline 11. & $\begin{array}{l}\text { Saya jarang absen jika tidak benar-benar } \\
\text { dalam keadaan mendesak }\end{array}$ & - & 1 & 3 & 3 & 24 & 4,61 \\
\hline 12. & $\begin{array}{l}\text { Saya selalu bekerja sama dengan baik } \\
\text { kepada rekan kerja saya }\end{array}$ & - & - & 2 & 4 & 25 & 4,74 \\
\hline 13. & $\begin{array}{l}\text { Saya merasa puas dan semangat bekerja } \\
\text { disini dengan kerja sama yang baik kepada } \\
\text { rekan kerja saya }\end{array}$ & - & - & 3 & 2 & 26 & 4,74 \\
\hline & & & & & 4,65 \\
\hline
\end{tabular}

Sumber : Hasil olah data 2019 
Berdasarkan tabel 4.7 dapat diketahui rata-rata jawaban responden untuk variabel Kinerja Karyawan sebesar 4,65. Hal ini dikarenakan Gaya kepemimpinan transformasional dan Semangat kerja karyawan Raffles City Hotel Bengkulu dapat memberikan perubahan dan manfaat mempengaruhi kinerja karyawan. Hasil tanggapan paling tinggi adalah dengan pernyataan saya merasa puas dan semangat bekerja disini dengan kerja sama yang baik kepada rekan kerja saya dengan rata-rata sebanyak 4,74 hal tersebut menunjukkan bahwa kerjasama memang sangatlah penting bagi perusahaan, dengan adanya kerjasama di dalam perusahaan maka karyawan akan merasa puas bekerja di perusahaan tersebut dan semakin bersemangat karyawan bekerja tentunya akan meningkatkan kinerja karyawan dan menguntungkan bagi perusahaan.

Hasil tanggapan paling rendah adalah dengan pernyataan saya menyelesaikan tugas yang diberikan dengan tepat waktu dengan rata-rata sebanyak 4,55 hal tersebut menunjukkan bahwa masih terdapat karyawan yang tidak dapat menyelesaikan tugas dengan tepat waktu karena adanya kendala dengan banyaknya beban kerja yang di kerjakan tentu menghambat ketepatan waktu dalam menyelesaikan pekerjaan, seharusnya atasan lebih mengerti dengan tugas-tugas yang di berikan kepada karyawannya, hal ini sangat perlu di atasi bagi pihak perusahaan, karena kasus tersebut sangat merugikan bagi pihak perusahaan itu sendiri, maka sangat penting jika hal ini harus diatasi agar kinerja karyawan tersebut tidak terkendala sehingga 
karyawan bisa menyelesaikan pekerjaan dengan tepat waktu agar kinerja perusahaan tidak terganggu dan akan menguntungkan bagi perusahan.

\subsection{Analisis Regresi Berganda}

Analisis regresi linear berganda digunakan dalam penelitian ini dengan tujuan untuk mengetahui ada tidaknya pengaruh variabel bebas terhadap variabel terikat. Perhitungan statistik dalam penelitian ini dengan menggunakan bantuan program spss for windows versi 16. Hasil analisis data berdasarkan hasil uji Regresi dapat dilihat pada tabel berikut:

\section{Tabel 4.8}

\section{Uji Regresi}

\section{Coefficients $^{a}$}

\begin{tabular}{|c|c|c|c|c|c|c|}
\hline \multirow{2}{*}{\multicolumn{2}{|c|}{ Model }} & \multicolumn{2}{|c|}{$\begin{array}{l}\text { Unstandardized } \\
\text { Coefficients }\end{array}$} & \multirow{2}{*}{$\begin{array}{c}\begin{array}{c}\text { Standardized } \\
\text { Coefficients }\end{array} \\
\text { Beta }\end{array}$} & \multirow[b]{2}{*}{$\mathrm{T}$} & \multirow[b]{2}{*}{ Sig. } \\
\hline & & B & Std. Error & & & \\
\hline \multirow[t]{3}{*}{1} & (Constant) & 7.175 & 2.440 & & 2.941 & .007 \\
\hline & $\begin{array}{l}\text { Gaya Kepemimpinan } \\
\text { Transformasional }\end{array}$ & 396 & .173 & .350 & 2.284 & .030 \\
\hline & Semangat Kerja & .512 & .151 & .519 & 3.387 & .002 \\
\hline
\end{tabular}

a. Dependent Variable: Kinerja Karyawan

Sumber : Hasil olah data 2019 
Berdasarkan tabel 4.8 didapatkan persamaan regresinya adalah : $7.175+0.396 \mathrm{X}_{1}+0.512 \mathrm{X}_{2}$. Angka tersebut masing-masing secara ekonomis dapat dijelaskan sebagai berikut :

1. Nilai konstanta 7.175. mempunyai arti bahwa apabila variabel gaya kepemimpinan dan semangat kerja terhadap kinerja karyawan, sama dengan nol, maka variabel kinerja karyawan akan tetap yaitu 7.175. Hal ini berlaku saat dilaksanakannya penelitian.

2. Koefisien regresi variabel gaya kepemimpinan transformasional sebesar 0.396 mempunyai makna bahwa apabila gaya kepemimpinan transformasional ditingkatkan satu satuan, maka akan meningkatkan kinerja karyawan Raffles City Hotel Bengkulu sebesar 0.396 dengan asumsi variabel gaya kepemimpinan transformasional untuk meningkatkan kinerja karyawan.

3. Koefisien regresi variabel semangat kerja sebesar 0.512 mempunyai makna bahwa apabila semangat kerja ditingkatkan satu satuan, maka akan meningkatkan kinerja karyawan Raffles City Hotel Bengkulu sebesar 0,512 dengan asumsi variabel semangat kerja untuk meningkatkan kinerja karyawan.

\subsection{Uji Determinasi}

Hasil analisis data berdasarkan hasil Uji Determinasi dapat dilihat pada tabel berikut: 
Tabel 4.9

Uji Determinasi

Model Summary ${ }^{\mathrm{b}}$

\begin{tabular}{|r|r|r|r|r|}
\hline Model & $\mathrm{R}$ & R Square & Adjusted R Square & Std. Error of the Estimate \\
\hline 1 & $.795^{\mathrm{a}}$ & .632 & .606 & 1.932 \\
\hline
\end{tabular}

a. Predictors: (Constant), Semangat Kerja, Gaya Kepemimpinan Transformasional

b. Dependent Variable: Kinerja Karyawan

Sumber : Hasil olah data 2019

Berdasarkan tabel 4.9 diketahui nilai $\mathrm{R}$ sebesar $79.5 \%=0,795$. Artinya hubungan antara variabel gaya kepemimpinan transformasional dan semangat kerja terhadap kinerja karyawan, ini terjadi hubungan linier.

Hasil analisis menunjukan nilai koefisien determinasi adjusted $\mathrm{R}=0.606$. Nilai ini mempunyai arti bahwa variabel gaya kepemimpinan transformasional dan semangat kerja terhadap variabel kinerja karyawan secara bersama-sama memberikan sumbangan sebesar $60.6 \%$ dalam mempengaruhi kinerja karyawan yang tidak diteliti dalam penelitian ini. 


\subsection{Pengujian Hipotesis}

\subsubsection{Uji t ( Parsial )}

Uji hipotesis ini dimaksud untuk mengetahui seberapa jauh pengaruh satu variabel independen (Gaya Kepemimpinan Transformasional dan Semangat Kerja) secara individual dalam menerangkan variabel dependen (Kinerja karyawan). Hasil analisis data berdasarkan hasil uji Hipotesis t dalam penelitian ini dapat dilihat pada tabel berikut:

Tabel 4.10

Hasil Uji t

\begin{tabular}{|c|c|c|c|c|c|c|}
\hline \multirow{2}{*}{\multicolumn{2}{|c|}{ Model }} & \multicolumn{2}{|c|}{$\begin{array}{l}\text { Unstandardized } \\
\text { Coefficients }\end{array}$} & \multirow{2}{*}{$\begin{array}{c}\begin{array}{c}\text { Standardized } \\
\text { Coefficients }\end{array} \\
\text { Beta }\end{array}$} & \multirow[b]{2}{*}{$\mathrm{T}$} & \multirow[b]{2}{*}{ Sig. } \\
\hline & & B & Std. Error & & & \\
\hline \multirow[t]{3}{*}{1} & (Constant) & 7.175 & 2.440 & & 2.941 & .007 \\
\hline & $\begin{array}{l}\text { Gaya Kepemimpinan } \\
\text { Transformasional }\end{array}$ & .396 & .173 & .350 & 2.284 & .030 \\
\hline & Semangat Kerja & .512 & .151 & .519 & 3.387 & .002 \\
\hline
\end{tabular}

Sumber : Hasil olah data 2019

Berdasarkan tabel uji hipotesis pada tabel 4.10 dapat diketahui :

Variabel gaya kepemimpinan transformasional nilai $t_{\text {hitung }}$ untuk variabel gaya kepemimpinan transformasional yaitu sebesar 2.284 dan nilai sig $0,030<0,050$ yang berarti terdapat pengaruh positif dan signifikan antara gaya kepemimpinan transformasional Raffles City Hotel Bengkulu. Artinya dengan meningkatnya gaya kepemimpinan transformasional yang diterapkan maka kinerja karyawan akan meningkat dan dengan sebaliknya jika menurunnya gaya kepemimpinan 
transformasional akan menurunnya kinerja karyawan. Dan dapat disimpulkan bahwa karyawan memperdulikan gaya kepemimpinan transformasional terhadap kinerja karyawan Raffles City Hotel Bengkulu sehingga hasilnya gaya kepemimpinan transformasional berpengaruh positif terhadap kinerja karyawan.

Variabel semangat kerja nilai $t_{\text {hitung }}$ yaitu sebesar 3.387. dan nilai sig 0,002 < 0,050 yang berarti terdapat pengaruh positif dan signifikan antara semangat kerja terhadap kinerja karyawan Raffles City Hotel Bengkulu. Artinya semangat kerja yang baik akan meningkatkan kinerja karyawan dan sebaliknya dengan tidak baiknya semangat kerja yang di lakukan maka kinerja karyawan akan menurun. Dan dapat disimpulkan bahwa perusahaan memperdulikan semangat kerja terhadap terhadap kinerja karyawan Raffles City Hotel Bengkulu sehingga hasilnya semangat kerja berpengaruh positif terhadap kinerja karyawan.

\subsubsection{Uji F (Simultan)}

Uji $\mathrm{F}$ digunakan untuk menguji ada tidaknya pengaruh variabel-variabel independen terhadap variabel dependen secara simultan (bersama-sama). Hasil analisis data berdasarkan hasil uji Uji Simultan (Uji F) dalam penelitian ini dapat dilihat pada tabel berikut: 


\section{Tabel 4.11}

\section{Hasil Uji F}

ANOVA $^{\text {b }}$

\begin{tabular}{|ll|r|r|r|r|r|}
\hline Model & & Sum of Squares & Df & Mean Square & F & Sig. \\
\hline 1 & Regression & 179.450 & 2 & 89.725 & 24.045 & $.000^{\mathrm{a}}$ \\
& Residual & 104.485 & 28 & 3.732 & & \\
& 283.935 & 30 & & & \\
& Total & & & & \\
\hline
\end{tabular}

a. Predictors: (Constant), Semangat Kerja, Gaya Kepemimpinan Transformasional

b. Dependent Variable: Kinerja Karyawan

Sumber : Hasil olah data 2019

Berdasarkan tabel 4.11 di atas, dapat dikatakan bahwa model regresi berganda ini baik. Artinya bahwa variabel gaya kepemimpinan transformasional dan semangat kerja berpengaruh terhadap kinerja karyawan ( $\mathrm{F}$ hitung $=24.045$; sig $>0,000$ ). Maka dapat dapat disimpulkan bahwa $(0.000<0.050)$ artinya bahwa secara bersama-sama variabel mempunyai pengaruh terhadap kinerja karyawan Raffles City Hotel Bengkulu.

\subsection{Pembahasan}

\subsubsection{Pengaruh Gaya Kepemimpinan Transformasional Terhadap Kinerja}

\section{Karyawan}

Hasil penelitian menunjukkan bahwa nilai signifikan untuk variabel gaya kepemimpinan transformasional sebesar 0,030, nilai tersebut lebih kecil dari 0,05 sehingga Ha diterima dan Ho ditolak yang berarti gaya kepemimpinan transformasional berpengaruh positif dan signifikan terhadap kinerja karyawan. 
Dengan demikian, hipotesis yang menyatakan bahwa gaya kepemimpinan transformasional berpengaruh positif terhadap kinerja karyawan terbukti.

Hal ini dapat menunjukkan bahwa ketika gaya kepemimpinan transformasional yang dibangun oleh Raffles City Hotel Bengkulu dengan mempengaruhi kinerja karyawan agar bisa bekerja lebih baik, kepemimpinan dapat dikatakan sebagai cara dari seseorang pemimpin dalam mengarahkan, mendorong serta mengatur seluruh unsur-unsur di dalam perusahaan untuk mencapai tujuan perusahaan yang diinginkan, kinerja karyawan akan baik apabila pemimpin dapat memberi motivasi yang tepat dan pemimpin memiliki gaya kepemimpinan yang dapat di terima oleh seluruh karyawan dan mendukung terciptanya suasana kerja yang baik, memberi dorongan kepada karyawan dan mampu mengajak karyawan agar melakukan perubahan ke arah yang lebih baik lagi serta memperhatikan para karyawan agar karyawan lebih merasa percaya lagi kepada atasannya,

Gaya Kepemimpinan Transformasional yang baik dimana seorang pemimpin dapat memberikan pengaruh yang baik terutama dapat memberikan contoh perilaku agar karyawan mau bekerja sama dan bekerja secara efektif dalam mencapai tujuan perusahaan, pemimpin yang memberikan contoh yang biak tentunya dapat disenangi oleh para karyawan, karena kebaikannya tersebut karyawan berani untuk menyampaikan pendapat, berkomunikasi dengan baik, dan memebrikan saran serta ikut langsung dalam mengambil keputusan, pemimpin yang baik juga memberikan image yang baik dimata karyawannya dan juga di hormati serta di hargai oleh para 
karyawannya serta melakukan penyesuaian secara terus menerus agar tercapainya kinerja perusahaan yang lebih baik lagi dan meningkatkan kinerja karyawan demi tercapainya tujuan perusahaan maka hal tersebut dapat memberikan keuntungan bagi Raffles City Hotel Bengkulu.

Hasil penelitian ini mendukung penelitian yang dilakukan oleh H.M.Nawawi D.Sibali (2012) bahwa adanya pengaruh antara gaya kepemimpinan transformasional terhadap kinerja karyawan. Hasil penelitian yang dilakukan Yuyun Fitri Astuti (2015) bahwa adanya pengaruh antara gaya kepemimpinan transformasional terhadap kinerja karyawan.

\subsubsection{Pengaruh Semangat Kerja Terhadap Kinerja Karyawan}

Hasil penelitian menunjukkan bahwa nilai signifikan untuk variabel semangat kerja sebesar 0,002, nilai tersebut lebih kecil dari 0,05 sehingga Ha diterima dan Ho ditolak yang berarti semangat kerja berpengaruh positif dan signifikan terhadap kinerja karyawan. Dengan demikian, hipotesis yang menyatakan bahwa semangat kerja berpengaruh positif terhadap kinerja karyawan terbukti.

Hal ini dapat menunjukkan bahwa ketika semangat kerja yang dibangun oleh Raffles City Hotel Bengkulu, mampu menciptakan suasana kerja yang baik, dapat mendukung kreativitas karyawan dalam bekerja, mampu membangkitkan semangat kerja para karyawannya, serta mampu meningkatkan prestasi para karyawannya dengan cara memberi perhatian terhadap waktu kerja karyawan agar karyawan bersemangat dalam menjalani pekerjaanya dan kinerja perushaan dapat terus berjalan 
dengan baik, pemimpin harus bisa menciptakan suasana kerja yang nyaman untuk karyawannya, karena semakin nyaman karyawan tersebut bekerja maka karyawan tersebut tentu akan semakin loyal dalam menjalani pekerjaannya tersebut serta semakin loyal karyawan tersebut bekerja maka akan semakin bersemangat lagi karyawan tersebut melakukan pekerjaannya, jika karyawan semakin bersemangat dalam menjalani pekerjaannya tentu akan menguntungkan bagi perusahaan, maka dari itu perlunya pimpinan yang mampu menciptakan suasana kerja yang baik.

Atasan perlu mendengarkan aspirasi dan ide kreatif karyawan siapa tau karyawan memiliki ide cemerlang dalam strategi pengambangan perusahaan, karena memiliki karyawan yang kreatif dan mau memberikan ide cemerlang, dengan mendengarkan ide kreatif dan juga aspirasi dari para karyawan ini bisa menambah semangat kerja karyawan, karena mereka dianggap sebagian dari tim perusahaan yang memiliki kemampuan yang sama untuk memajukan kualitas perusahaan, lalu jalin hubungan komunikasi yang baik dengan karyawan, karena sebagai atasan tidak baik jika hanya membatasi hubungan dengan rekan sepangkat saja perlu juga membuka hubungan komunikasi yang baik dengan karyawan agar karyawan semakin bersemangat dalam bekerja, karena dengan semangat kerja yang baik tentunya kinerja di dalam perushaan tersebut akan terus meningkat sehingga akan mempengaruhi kinerja karyawan Raffles City Hotel Bengkulu dan semakin berkembang.

Hasil penelitian ini mendukung penelitian yang dilakukan oleh Ishak Syahropi (2016) bahwa adanya pengaruh antara semangat kerja terhadap kinerja karyawan. 
Hasil penelitian Ihsan Najamuddin (2010) bahwa adanya pengaruh semangat kerja terhadap kinerja karyawan. 


\section{BAB V \\ KESIMPULAN DAN SARAN}

\subsection{Kesimpulan}

Dari analisis yang dilakukan pada penelitian tantang "Pengaruh Gaya Kepemimpinan Transformasional dan Semangat Kerja terhadap Kinerja Karyawan Raffles City Hotel Bengkulu” dapat disimpulkan sebagai barikut:

1. Gaya Kepemimpinan Transformasional berpengaruh positif dan signifikan terhadap Kinerja Karyawan Raffles City Hotel Bengkulu. Hal ini dibuktikan dengan hasil uji t dengan signifikansi $(0,030<0,05)$. Hal ini Ho ditolak dan Ha diterima.

2. Semangat Kerja berpengaruh positif dan signifikan terhadap Kinerja Karyawan Raffles City Hotel Bengkulu. Hal ini dibuktikan dengan hasil uji t dengan signifikansi $(0,002<0,05)$. Hal ini Ho ditolak dan Ha diterima.

3. Gaya Kepemipinan Transformasional dan Semangat Kerja secara bersama-sama berpengaruh positif dan signifikan terhadap Kinerja Karyawan Raffles City Hotel Bengkulu. Hal ini di buktikan dengan hasil uji F dengan signifikansi $(0,000<$ 0,05). Hal ini Ho ditolak dan Ha diterima.

\subsection{Saran}

Berdasarkan kesimpulan diatas ada dua saran yang diajukan oleh peneliti sebagai berikut: 
1. Bagi perusahaan

1). Berdasarkan hasil yang telah diperoleh, beberapa saran di perlukan untuk dapat memberikan masukan berupa ide atau pemikiran sehingga nantinya dapat meningkatkan perusahaan, khususnya pada Gaya kepemimpinan Transformasional dan Semangat Kerja. Faktor-faktor tersebut terbukti berpengaruh terhadap kinerja karyawan oleh sebab itu diharapkan kepada Raffles City Hotel Bengkulu agar gaya epemimpinan Transformasional dan Semangat Kerja dapat dipertahankan serta ditingkatkan sehingga tujuan perusahaan dapat tercapai dan kinerja karyawan semakin meningkat.

2). Berdasarkan hasil penelitian karyawan di Raffles City Hotel diketahui bahwa variabel Gaya Kepemimpinan Transformasional mendapatkan skor terendah dengan rata-rata 4,45 pada indikator karisma. Oleh karena itu, Manager Raffles City Hotel disarankan untuk menyampaikan visi dan misi tujuan perusahaan dengan jelas guna untuk para karyawan agar tau tujuan perusahaan Raffles City Hotel tersebut.

3). Berdasarkan hasil penelitian karyawan di Raffles City Hotel diketahui bahwa variabel Semangat Kerja mendapatkan skor terendah dengan rata-rata 4,23 pada indikator kualitas untuk bertahan. Oleh karena itu Manager Raffles City Hotel disarankan untuk, tidak terlalu banyak memberikan beban kerja kepada karyawan sehingga menimbulkan semangat kerja karyawan menurun akibat tuntutan beban kerja yang terlalu banyak, karena karyawan juga perlu merasakan kenyamanan dan 
kepuasan dalam menjalani kerja tersebut agar semakin bersemangat dalam bekerja dan tentunya akan meningkatkan kinerja karyawan.

\section{Bagi peneliti selanjutnya}

Pada penelitian ini diketahui ada dua variabel yang berpengaruh terhadap kinerja karyawan Raffles City Hotel Bengkulu yaitu variabel gaya kepemimpinan transformasional dan semangat kerja. Sebaiknya peneliti selanjutnya diharapkan mencari dan menganalisis faktor lain. 


\section{DAFTAR PUSTAKA}

Anjani, R. (2019). Tata Kelola Adminitrasi Keuangan, Dan Pembangunan Desa Tepi Laut Kabupaten Bengkulu Utara. Jurnal Pengabdian Masyarakat Bumi Raflesia, 2 (2).

Asmawi, M. (2017). The effect of compensation, empowerment, and job satisfaction on employee loyalty. International Journal of Scientific Research and Management, 5(12), 7590-7599.

A. Anwar Prabu Mangkunegara. (2006). Evaluasi Kinerja Sumber Daya Manusia. Refika Aditama. Jakarta.

Akbar P.S dan Usman. (2008). Pengantar Statistika, Jakarta: Bumi Aksara

Arifin, Zainal. (2014). Penelitian Pendidikan : Metode dan Paradigma Baru. Bandung : Remaja Rosdakarya.

Arikunto, Suharsimi. (2006). Prosedur Penelitian. Jakarta: Rineka Cipta.

Astuti, Yuyun, Fitri. (2015). Pengaruh Gaya Kepemimpinan Transformasional Dan Kompensasi Terhadap Kinerja Karyawan Pada Karyawan Pamella Supermarket 7. Skripsi Universitan Negeri Yogyakarta

Aulia, Yasha. (2016). Pengaruh Gaya Kepemimpinan Transformasional Terhadap Kinerja Karyawan Pt. Wahanamegaputra. Skripsi Universitas Haluoleo Kendari

Balansa, Fandy.dkk. (2017) Pengaruh Gaya Kepemimpinan Transformasional, Budaya Organisasi Dan Disiplin Kerja Pada Pt. Pegadaian (Persero) Kantor Cabang Karombasan. Jurnal EMBA Vol.5 No.3 September 2017, Hal.4555-4564

Bass, B. M., dan Avolio, B. J. (2003). MLQ: Multifactor Leadership Questionnaire: Technical Report, Leader Form, Rater and Scoring Key for $M L Q$ (form 5x-Short), CA. Redwood City: Mind Garden.

Devintasari, Farantia Dindy. (2016). Pengaruh Gaya Kepemimpinan Transformasional Dan Transaksional Terhadap Kinerja Karyawan Dengan Quality Of Work Life Sebagai Variabel Moderasi (Studi Empiris Pada Rumah Sakit Di Kabupaten Temanggung). Skripsi Universitas Negeri Yogyakarta

Ferdinand. 2006. Metode Penelitian Manajemen. Semarang: Badan Penerbit Universitas Diponegoro. 
Ghozali, Imam. (2009). Aplikasi Analisis Multivariate Dengan Program SPSS. Edisi Keempat. Semarang: Universitas Negeri Yogyakarta.

Ghozali, Imam. (2011). Apkikasi Analisis Multivariate dengan Program IBM SPSS 19. Edisi 5. Semarang : Badan Penerbitan Universitas Diponegoro.

Ginting, Febby, Novianti. (2018). Pngaruh Semangat Kerja Dan Promosi Jabatan Terhadap Kinerja Karyawan Pada Pt. Indah Traso Medan. Skripsi Universitas Medan Area Medan

Hadari Nawawi, (2003). Manajemen sumber daya manusia untu bisnis yang kompititif, Gadjah Mada University Press, Yogyakarta

Halsey, George D.Bagaimana Memimpin dan Mengawasi Pegawai Saudara, Rineka Cipta, Jakarta, 2003.

Hamali, Arif Yusuf. 2016. Pemahaman Sumber Daya Manusia. Yogyakarta : CAPS

Harefa, Stevent Rian Valenthino, 2009. Pengaruh Semangat Kerja Terhadap Kinerja Pegawai Kantor Camat Rumbai Pesisir. Skripsi. Fakultas Ekonomi Universitas Islam Riau Pekanbaru.

H.M Nawawi D. Sibali, Pengaruh Gaya Kepemimpinan Transformasional Terhadap Kinerja Karyawan PT Berau Koal Kabupaten Berau Jurnal Eksis, Vol.8 No.1, Mar 2012 : 2001 -2181

Kiptiyah, Marisatul. (2015). Pengaruh Gaya Kepemimpinan Transformasional Dan Kompensasi Terhadap Kinerja Karyawan Pt Madu Baru Pg/Ps Madukismo. Skripsi Universitas Negeri Yogyakarta

Magdalena, Corry.dkk. (2016). Pengaruh Kepemimpinan Transformasional Dan Kepemimpinan Transaksional Terhadap Kinerja Karyawan Dengan Motivasi Sebagai Variabel Intervening Pada PT Sinar Sosro Tanjung Morawa. HUMAN FALAH: Volume 3. No. 1 Januari - Juni 2016

Maulizar et al. (2012). Pengaruh KepemimpinanTransaksional dan Transformasioal terhadap Kinerja Karyawan Bank Syariah Mandiri Cabang Banda: Jurnal Manajemen Pascasarjana Universitas Syiah Kuala Volume 1, No. 1, Agustus 2012, Hal : 58-65.

Mondiani, J. 2012. Pengaruh Kepemimpinan Transformasional Dan Kompensasi Terhadap Kinerja Karyawan Pln (Persero) Upj Semarang Jurnal Administrasi Bisnis.

Mondiani, Tria. 2012 "pengaruh kepemimpinan transformasional dan kompensasi terhadap kinerja karyawan PT. PLN (PERSERO) UPJ SEMARANG”. Jurnal Administrasi Bisnis Volume 1 September 2012.

Murvi, Dikki. (2015) Pengaruh Gaya Kepemimpinan Terhadap Kinerja Karyawan The Palais Dago Hotel. E-Proceeding Of Management : Vol.2, No.1 April 2015 
Nadjamuddin, Ihsan. (2010). Pengaruh Semangat Kerja Dan Kecerdasan Emosional Terhadap Kinerja Karyawan Studi Kausal Wisma Bantimurung Jakarta Jurnal IImiah Penelitian Manajernen Manajerial Vol. 8 No.2 September 2010

Niswati, Sulistatun. (2016). Pengaruh Kompensasi Finansial, Semangat Kerja Dan Disiplin Kerja Terhadap Kinerja Karyawan Pada Ud Sumber Utama Kediri

Nitisemito, 2010. Manajemen Personalia, Ghalia Indonesia, Jakarta

Notoatmodjo, Soekidjo. 2003. Pengembangan Sumber Daya Manusia, Jakarta: Rineka Cipta.

Nugroho, Adi, wahyu,. sudaryanto, budi. (2013), pengaruh kinerja layanan, kepercayaan dan kepuasan terhadap loyalitas konsumen dalam menggunakan jasa pengiriman barang. Journal of management volume 2, Nomor 3, tahun 2013 halaman 1-9

Nurhendar, Siti. (2007). Pengaruh Stress Kerja Dan Semangat Kerja Terhadap Kinerja Karyawan Bagian Produksi ( Studi kasus pada CV aneka ilmu semarang), Semarang

Nurmansyah, 2011. Manaemen Sumber Daya Manusia Suatu Pengantar. Unilak Press, Pekanbaru

Northouse, Peter G. 2013. Kepemimpinan Teori dan Praktek. Edisi Keenam.Indeks. Jakarta

Onsardi, O. (2019). Effect Of Empowerment On Employees Performance (No. v7g9t). Center for Open Science.

Onsardi, O. (2019). Implementasi Manajemen Kinerja Di Universitas Muhammadiyah Bengkulu (No. kzyfx). Center for Open Science.

Onsardi, O. (2018). Loyalitas Karyawan pada Universitas Swasta di Kota Bengkulu. COSTING: Journal of Economic, Bussines and Accounting, 2(1), 1-13.

Onsardi, O. (2019). Implementasi Empowerment Dalam Meningkatkan Kinerja Karyawan (No. bgwju). Center for Open Science.

Panggabean, S, Mutiara. 2002. Manajemen Sumber Daya Manusia. Jakarta : Ghalia Indonesia

Paracha, M. U., Qamar, A., Mirza, A., Inam-Ul-Hassan \& ., H. W. 2012.Impact Of Leadership Style(Transformational \& TransactionalLeadership) On EmployeePerformance \& Mediating Role Of Job Satisfaction" Study Of PrivateSchool (Educator) In PakistanGlobal Journal Of ManagementAnd Business Research, 12, (4):5564. 
Pradeep, D. D. \& Prabhu, N. R. V. 2011. The Relationship Between Effective Leadership And Employee Performance International Conference On Advancements In Information Technology With Workshop Of Icbmg, 20, 198-207.

Pratama, Abdul Aziz Nugraha. (2017). Pengaruh Kemampuan Kerja dan Semangat Kerja Terhadap Kinerja Karyawan Melalui Kepuasan Kerja (Studi Kasus Bank Syariah Mandiri Kantor Cabang Kendal). Muqtasid 8(2), 2017:

Perbankan

Syariahhttp://muqtasid.iainsalatiga.ac.idDOI:http://dx.doi.org/10.18326/mu qtasid.v8i2.119-129

Prawirosentono, Suryadi. 2008. Kebijakan Kinerja Karyawan. Yogyakarta:BPFE

Priyatno, 2010. Teknik mudah dan cepat melakukan analisis data penelitian dengan SPSS. Yogyakarta: Gava Media

Priyanto, Wahyu,Budi. (2016). Pengaruh Gaya Kepemimpinan Transformasional Dan Kompensasi Terhadap Kinerja Karyawan Dengan Motivasi Sebagai Variabel Intervening. http://ejournal.umm.ac.id/index.php/jeb Ekonomika-Bisnis Vol. 07 No. 02 Bulan Juli Tahun 2016 Hal 105-114p-ISSN : 2088-6845 e-ISSN : 2442-8604

Putri, Sekar, Nindita, Adila. (2016). Pengaruh Gaya Kepemimpinan Transformasional Terhadap Kinerja Karyawan (Studi Kasus Pada Pt. Bank Rakyat Indonesia (Persero) Tbk Kantor Cabang Ngawi Jawa Timur) EProceeding Of Management : Vol.3, No.2 Agustus 2016

Richard, Y. Sangki, Dkk. Lingkungan Kerja, Budaya Kerja dan Semangat Kerja Terhadap Kinerja Karyawan Outsourcing Pada Grapari Telkomsel Manado. Jurnal EMBA 539 Vol.2 No.3 September 2014, ISSN 2303-1174 Hal. 539-549.

Rikindaka Awaliwinda.dkk. (2014). Pengaruh Lingkungan Kerja, Semangat Kerja, Budaya Kerja Dan Keselamatan Kerja Terhadap Kinerja Karyawan

Robbins, S. P. \& Judge, T. A. 2015. Perilaku Organisasi, Jakarta, Salemba Empat.

Robbins, Stephen P. 2010. Prilaku Organisasional, Jilid I dan II. Salemba Empat: Jakarta.

Setiawan, Ferry dan Dewi, Kartika. 2014. Pengaruh Kompensasi Dan Lingkungan Kerja Terhadap Kinerja Karyawan pada CV. Berkat Anugrah. Bali: Universitas Udayana.

Siagian, S. P. (2003). Teori dan praktek kepemimpinan (cetakan kelima). Jakarta: Rineka Cipta.

Siswanto, Bedjo, Manajemen Tenaga Kerja, Bumi Aksara, Jakarta, 2002

Sugiyono, 2010. Metode Penelitian Kombinasi (mixed Methods). Bandung : Alfabeta 
Sugiyono, (2013). Metode penelitian kuantitatif dan kualitatif dan R \& D. alfabeta. Bandung

Syahropi, Ishak. (2016). Pengaruh Semangat Kerja Terhadap Kinerja Karyawan PT. Bangkinang di Pekanbaru ( Studi kasus pada karyawan tetap PT. Bangkinang). Volume 3 (2) : 02. Diunduh 08-04-2018

Tohardi. 2006. Pemahaman Praktis Manajemen Sumber Daya Manusia, Bandung: Mandar Maju.

Sugiyono, (2016). Metode penelitisn Kuantitatif kualitatif dan kombinasi (Mixed Methods). Bandung : Alfabeta.

Umam, Khaerul. (2010). Perilaku Organisasi. Bandung : CV Pustaka Setia

Umi, Narimawati. Metodologi penelitian kualitatif dan kuantitatif, Teori dan Aplikasi. Bandung: Agung Media

Wardani, Aprina. (2017). Pengaruh Kemampuan Kerja Dan Semangat Kerja Terhadap Kinerja Karyawan Melalui Kepuasan Kerja Sebagai Variabel Intervening (Studi Kasus Bank Syariah Mandiri Kantor Cabang Kendal). Skripsi Institut Agama Islam Negeri Salatiga

Yofandi, Ahmad. (2017). Pengaruh Konflik Kerja, Stres Kerja, Dan Semangat Kerja Terhadap Kinerja Karyawan Pada Jom Fekon, Vol 4 No. 1 (Februari) 20171015 Pt. Perkebunan Nusantara V (Persero) Pekanbaru. Vol 4 No. 1 (Februari) 2017

Yukl, Gary. (2009). Kepemimpinan dalam Organisasi. Jakarta: Indeks.

Yunida, Sri. (2016). Pengaruh Disiplin, Semangat Kerja Dan Lingkungan Kerja Terhadap Kinerja Karyawan Pada Klinik Insani Muara Teweh. Vol.3 No.6 Juli 2016. Skripsi Universitas Nusantara Pgri Kediri

Yusuf, Muri. (2014). Metodelogi penelitian kuantitatif, kualitatif dan penelitian gabungan. PRENAMEDIA GROUP. Jakarta 